\title{
Mine 9 år i Højer
}

\section{Af Poul Andersen}

Poul Andersen er født 1912 og opvokset i Århus. Efter realeksamen og læreår ved landbruget købte han, da han havde sat sig som mål at blive bonde i Nordslesvig, i 1935 Søgård ved Højer. I 1944 købte han Nørmark ved Visby. I 1953 forlod han landbruget og har siden levet som forsikringsmand i Tønder, Odense og fra 1972 på Munkemølle, Gråsten. Her har han stiftet Historisk forening for Gråsten og omegn og det lokalhistoriske arkiv i Gråsten.

Den 21. feb. 1935 ankom jeg til Tønder og skiftede her tog til Højer. Der var dengang endnu persontog til Højer med stop ved stationerne i Møgeltønder og Daler, så turen på de $13 \mathrm{~km}$ tog en halv time. Der var ingen modtagelseskomité, da jeg stod af toget; men jeg tog det som en venlig velkomst, at noget af det første jeg så, var et vajende dansk flag, ikke hejst til ære for mig, men byens danske læge havde den dag fået en $s ø n$, og det blev markeret. Det regnede og blæste. Det sidste gør det altid i marsken, vi plejede at sige, at der var elleve stille dage om året. Til fods begav jeg mig på vej ud ad diget mod Rudbøl for at nå frem til Søgård, som jeg havde købt til overtagelse d. 1. april. Med i handelen var den aftale, at jeg kunne bo på gården og få kosten hos gårdens forpagter, sådan at jeg kunne begynde at forberede forårsarbejdet.

Søgård ligger midt i Højer kog. Nu passerer en asfalteret vej tæt forbi gården; men dengang var det $\mathrm{i}$ vinterhalvåret nemmest at komme til gården, hvis man ikke var kørende med hest og vogn, ved at gå på diget mod Rudbøl. To km ude drejede man fra og fulgte en markvej ind i kogen; men de sidste ca. $500 \mathrm{~m}$ til gården måtte man gå tværs over fennerne, der var adskilt med brede grøfter. For at gøre det »bekvemt«, var der lagt brædder over grøfterne, så man nogenlunde tørskoet, dog altid iført gummistøvler, kunne komme til gården.

I de ni år, jeg boede på Søgård, var den her beskrevne vej, den vi benyttede i vinterhalvåret. På gården iførte vi os gummistøvler, tog 
skoene $\mathrm{i}$ hånden, vandrede over markerne til diget, hvor vi $\mathrm{i}$ et fåreskur havde vore cykler, og så på cykel de to km til Højer. Den tur har jeg gjort utallige gange alene, og senere sammen med min kone. Var man ikke stedkendt, kunne det en tåget nat godt være vanskeligt at finde frem. Intet lys til at lede én i den rigtige retning. En vinter gjorde jeg turen to gange om ugen, da jeg ledede gymnastik for karleholdet, og hertil kom så andre aftener, hvor der var møde i forsamlingshuset. Underligt at mindes idag, hvor man kun kan færdes med bil. Dengang var det en såre naturlig ting.

Der var en vej til gården. Vej er måske et fint ord, men fra Højer udgik Kovej, der det første stykke var belagt med sand, men derefter var det ganske enkelt marskjord med en grøft på begge sider, og i tiden fra oktober til april var dette stykke nærmest et bundløst ælte, og to heste kunne blive svedt af at trække en arbejdsvogn. Så det ud til frost, måtte man være agtpågivende, for så skulle vejen slæbes over, så de dybeste huller og hjulspor blev jævnede, for nåede man det ikke, inden frosten satte ind, risikerede man, at hestenes ben blev ødelagte, og vognen brød sammen.

Også om foråret skulle vejen slæbes, og når sol og blæst tørrede den af, kunne den være som et lerstampet logulv, dog sjældent så jævnt, men dog således at vi kunne cykle på den, og biler kunne også benytte den. Men blev det så regnvejr, og det regnede mere end en halv time, så var færdsel med cykel og bil umulig. Mere end én gang er det hændt, når vi havde bilende gæster, at vi måtte spænde heste for bilen, når de skulle hjem, fordi det var blevet regnvejr, mens de besøgte os. Elektrisk lys var der ikke på gården. Vi klarede os med petroleumslamper. Vore gæster fandt altid, det var så hyggeligt; men de skulle heller ikke arbejde $i$ hus og stald ved skæret fra petroleumslampe og flagermuslygte.

Vand fandtes heller ikke på gården. Jo, der var en brønd i stalden; men det var brakvand. Det kunne bruges til vanding af kreaturerne; men $\mathrm{i}$ husholdningen var det uanvendeligt. Vand til husholdningsbrug måtte vi, som det var almindeligt på mange marskgårde, skaffe os ved at samle regnvand fra taget, så helt rent var vandet ikke, da tagbeklædningen var tagpap. Det hjalp, da jeg senere lagde pandeplader på. Kom vi om sommeren ind i en tørketid, måtte vandet rationeres, og spændende var det, når det så trak op til torden, for så tømte vi det sidste vand ud af cisternen. Den blev 
skrubbet og kalket, og alt var klart til en frisk vandforsyning; men drev tordenbygen forbi, måtte vi, til der kom regn, hente vand $\mathrm{i}$ mejerispande fire $\mathrm{km}$ borte $\mathrm{i}$ Højer. Man forstår godt, at befolkningen i marskegne ikke er de store vanddrikkere, $i$ al fald ikke uden de kommer rom i.

Om bageren i Rudbøl, der fik sin vandforsyning fra stråtag, blev det fortalt, at der var to vandtønder, en til rugbrød og en til finere bagværk. I tønden til rugbrød blev det første vand ledet ned. Når så taget var skyllet nogenlunde rent, blev nedløbsrøret drejet hen til den anden tønde. Det kan dog være en legende.

Det var til denne Søgård, der i egnens dialekt blev kaldt »æ sjæv«, hvilket skal udlægges som sivsø eller sump, jeg hin februardag rettede mine skridt. Det var denne gård med sine mangler på vej, vand og lys, men med 30 ha marskjord, jeg havde købt, for $i$ marsken ville jeg bo'og gerne i Højer, hvor den nationale kamp stod strid og kraftig. Endnu i 1935 var stillingen i byrådet 7 tyske mod 4 danske, så vi danske var udpræget i mindretal, hvilket skabte spænding i hverdagen. Man kunne ikke undgå at engagere sig, og netop dette at kunne være med i et fagligt og folkeligt arbejde i et af de sogne, hvor tyskheden var stærk, var det, jeg gerne ville.

For at forøge de beskedne indtægter en bonde havde i de år - min første høst solgte jeg for $8 \mathrm{kr}$. pr. $100 \mathrm{~kg}$. - skrev jeg af og til nogle "Breve fra Marsken« til Dagens Nyheders søndagstillæg.Selv om det nu så mange år efter kan virke lidt ungdommeligt, giver det dog et billede af den tro på fremtiden, jeg begyndte min tilværelse $\mathrm{i}$ Højer med. Det hedder i dette første marskbrev:

\section{Foden under eget bord}

Gårdejer, ja, jeg har vovet det. Jeg er sprunget ud i bølgerne, som i brændingen knuses med harmfulde brøl om konvertering, korntold, krise, svinekort og alle andre mulige og umulige besværligheder, som nutidens agerdyrker har at slås med.

Men ungdommen er modig, vi er næsten for optimistiske. Vi tager et lån, og bevæbnet med en mægtig selvtillid styrter vi os ud $i$ problemerne, stolende på at vi skal nok klare det.

$\mathrm{Nå}$, det var gården. Jeg tror, det er den lavest liggende gård i 
kongeriget, så noget kan jeg prale med, den ligger kun $20 \mathrm{~cm}$ over havets overflade, ene og forladt i den udstrakte marsk.

Der er plads til at strække øjnene, ikke et træ, ikke et hus bryder synsfeltet. Langt ude mod vest stiger havdiget i vejret og synes at gå $i$ ét med horisonten. Henne ved diget står et par gamle vejrmøller, deres tid er forbi, de er afløst af moderne pumpestationer, der med masser af hestekræfter skal holde vandet fra marsken.

Marsken er storslået, en mægtig græsplæne på 5.000 ha, som er gennemskåret af et utal af grøfter, der har til opgave at lede vandet hen $\mathrm{i}$ de lidt større kanaler, og herfra pumpes vandet ud i Vidåen, der på et stykke af sit løb er landets sydgrænse.

Denne mægtige flade har noget af hedens betagende magt over sig, men den virker aldrig trist eller fattig. Selv på en kold, barsk, blæsende efterårsdag er der fylde over marsken. Man aner de store muligheder, der ligger gemt her, hvor græsset ser så frodigt ud. Veje findes ikke, kun på digerne, disse mægtige bygningsværker, som det har kostet slid og slæb at bygge, kan man færdes.Nutiden med gravkøer og andre tekniske hjælpemidler kommer lettere over digebyggeri end marskbønderne, der i det 16. århundrede rejste det dige, om hvilket berettes, at kvinderne bar jorden sammen til den høje vold i deres forklæder.

For at gøre digevejen fast, brændte man klinker, og med disse blev digerne brolagte. Brolægningen holdt et spand af tid, og endnu findes den, men bilernes stadig voksende skare har sat Dunlop og Firestones stempel i dybe hjulspor.

I gamle dage bestod marskbondens virksomhed $i$ at jage studene på græs om foråret, hvorefter han tændte piben og i øvrigt fik tiden til at gå ved dagligt at føle, om høvederne var blevet federe, samt med handel og grogdrikning på kroen. Det går ikke længere an, hvis man vil klare sig økonomisk.- - -

I et drømmesyn ser jeg faste veje ligge gennem marsken, jeg ser gårde skyde $i$ vejret og markerne bugne af gyldne afgrøder. Ja, alt dette vil nok vare nogle år, men forhåbentlig bliver det virkelighed.

Dannebrog vifter hver søndag fra min flagstang til hagekorsene $i$ det tredie rige. Der er nemlig en anden opgave foruden marskens kultivering, det nationale spørgsmål, og det er ikke mindre. Kongstanken er at forene begge opgaver. Ja, sådan lød ordene i dette udsnit af marskbrevet fra 1935. Der 


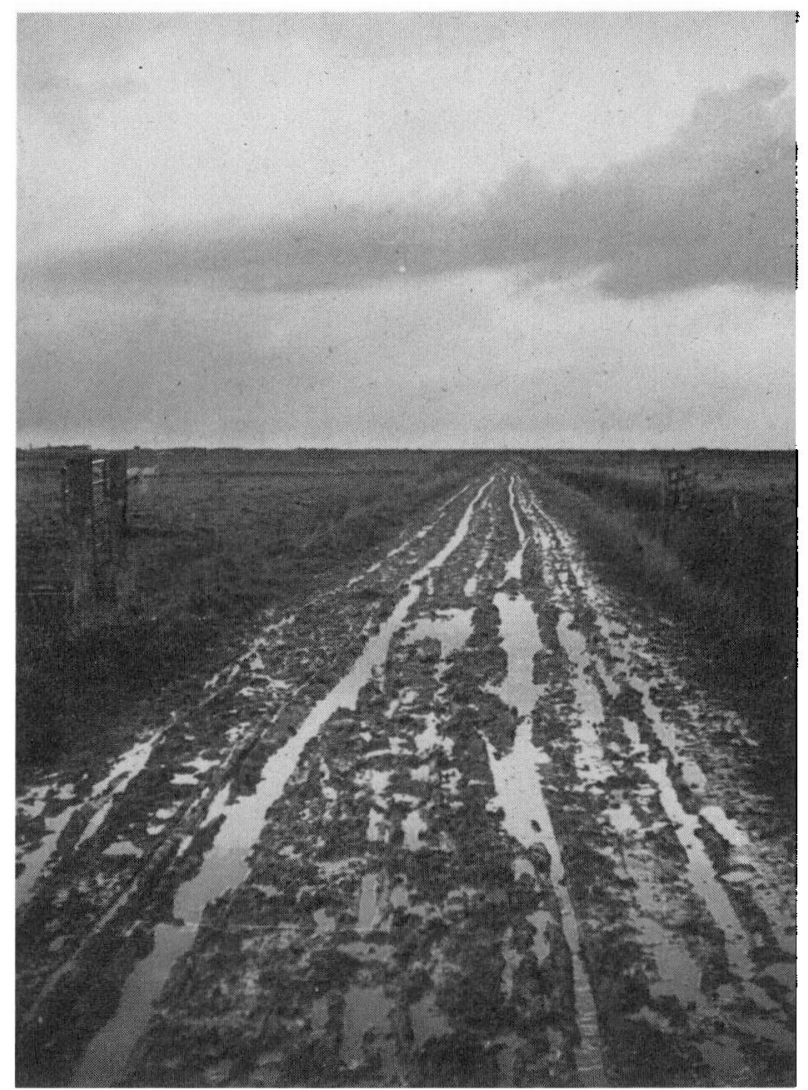

Vejen til Søgård - et fire kilometer langt, bundløst alte de syo måneder af året. (Privat eje)

skulle gå mere end 25 år, før der kom fast vej til Søgård. Vandledninger forsyner nu marskens gårde, lys og kraft er indlagt; men landbrugets udvikling har medført, at den store bebyggelse af marsken er udeblevet, selv om der er kommet flere ejendomme, og der er sket en jordfordeling, så mulighederne for mere rationelt landbrug er til stede.

Forpagteren, hos hvem jeg havde nydt gæstfrihed, rejste d. 1. april. Nu var det mig, der var mand på gården, og samtidig med at 
flyttevognen rullede ind med mit indbo, ankom karl og pige. Det blev travle dage.

Nye koste fejer bedst, og jeg havde mange planer om gårdens drift, reparationer og indretning af bygningerne. Jeg ville have nyt tag på, jeg fik undersøgt jorden for kalktrang, og det resulterede i, at jeg sommeren 1936 fik hele gården merglet. Året efter fik jeg lavet en dræningsplan og fik alle 30 ha drænet. Disse to grundforbedringer blev at mærke på jordenes ydeevne. Gårdspladsen var nærmest et morads, så den blev delvis brolagt, i øvrigt planeret og belagt med grus, og midt i blev anlagt en græsplæne. Der var lidt have til Søgård, men kun nogle få vindblæste pile. Jeg bestilte træer og buske og plantede et læbælte omkring haven. De første år, måtte vi nu ligge på plænen, hvis vi ville være i læ. Der var således altid nok at tage fat på, men det er morsomt at se tingene og planerne, man arbejder med, trives og ført ud i livet.

Så kom kornet op, de sorte agre blev lysegrønne, kreaturerne kom på græs, lammene hoppede på stive ben i solen, og »der var så dejligt derude på landet. "Med den jordfordeling, der var i marsken, havde jeg mange naboer. Ikke mindre end $\mathbf{4 2}$ forskellige naboers jord stødte op til Søgårds marker, og heraf var de 36 hjemmetyskere. Jeg var på det tidspunkt den eneste danske bonde i Højer sogn, men mine 30 ha var dog ikke de eneste, der var på danske hænder. I Højer, Daler og Møgeltønder var der folk, der ejede en fenne hist og her, og så var der offentlig jord, jord, der tilhørte legater; men langt den meste jord var på tyske hænder. Jeg var i $1935 \mathrm{med}$ til at foretage en undersøgelse om den nationale jordfordeling $\mathrm{i}$ »den truede firkant«, og jeg har tallene fra det år.

\begin{tabular}{lccrr} 
& Antal & \multicolumn{3}{c}{ Areal } \\
Højer sogn & ejere & \multicolumn{1}{c}{$\%$} & \multicolumn{1}{c}{ ha } & $\%$ \\
Danske & 11 & 14,1 & 52,42 & 5,2 \\
Tyske & 51 & 65,3 & 832,26 & 82,1 \\
Ubestemte & 4 & 5,1 & 11,14 & 1,0 \\
Offentlig jord & 12 & 15,5 & 119,38 & 11,7
\end{tabular}

Tallene viser med al tydelighed, hvor svagt danskheden stod jordmæssigt i Højer sogn. Det var da også med en vis tilfredsstillelse, jeg i oktober 1935 erhvervede næsten 3 ha, der lå ind til min 
jord. Den hjemmetyske sælger måtte høre en del bebrejdelser for dette jordsalg til mig.

Som nævnt havde jeg 36 hjemmetyske naboer; men jeg må sige, at forholdet os imellem altid var godt. Selv da besættelsen kom, og stemningen blev pisket $\mathrm{i}$ vejret, har jeg aldrig mødt uvilje. Ja, en del af dem, og det var de mest betydende, forsøgte, da jeg blev arresteret af Gestapo, at få mig løsladt. At man ikke så skævt til den unge danske bonde, der var flyttet ud i marsken, fik jeg ganske kort efter april 1935 et tydeligt bevis for fra tysk side.

Forholdet var det, at jeg havde nogle græsarealer, hvor jeg gerne ville fede nogle stude. Studehandel var et punkt, jeg vidste meget lidt om; men jeg tog til Tønder marked for at se og lære. Jeg så en række stude, 10 stykker som jeg fik lyst til. Sælgeren var Christian Rathenburg i Daler. Vi kendte ikke meget til hinanden. Han var en af mine naboer, og vi havde talt sammen en enkelt gang i marken. Jeg vidste, han var tysk, og han, at jeg var dansk. Vi blev enige om en pris; men så måtte jeg bekende, at det i øjeblikket var lidt småt med kontanter. »Du kan betale til efteråret «, sagde Rathenburg. Jeg takkede for dette for mig fordelagtige tilbud og foreslog, at vi skulle nedskrive, at jeg skyld te ham et beløb. »Jeg ser ind en dag, jeg er i marken, så kan vi ordne det«, var hans svar.

Det blev sommer, det blev efterår, uden at Christian Rathenburg var kommet. Studene blev solgt, og jeg tog til Daler og betalte min gæld. Jeg har ofte tænkt på, at det var en fantastisk tillid, han viste mig. Jeg havde været på egnen i et par måneder, og så lånte han mig på mit glatte ansigt ca. $2.000 \mathrm{kr}$. Vi blev senere særdeles gode venner. Vi var og kunne naturligvis ikke være enige, hvis vi drøftede forholdet mellem dansk og tysk; men drøfte det kunne vi. Da han hørte, at jeg var taget af Gestapo, var han den første, der besøgte min kone, for at tilbyde sin hjælp.

De tyske bønder i Højer, som jeg i de kommende år skulle komme i nærmere berøring med i Højer kogsbestyrelse og i Bønderkommunen, var selvbevidste,stoute vestslesvigere. De var præget af, at deres slægter gennem århundreder havde ejet jorden og gårdene og spillet en dominerende rolle i Højer. Deres tyskhed havde sine rødder $i$ det slesvig-holstenske oprør. Indtil da havde de været kongens loyale undersåtter, og deres omgangssprog var sønderjysk. Det var granvoksne folk, som unge, flotte mænd. Når 
de blev ældre, sås det, at de levede godt uden for meget legemeligt arbejde, men til gengæld lidt flere mørkningsgrogger. De havde fået en god skolegang og var ikke hjemmefødinge. De havde lært landbrug på herregårde $\mathrm{i}$ Holsten og for også at snuse til dansk landbrug som regel haft pladser på Sjælland. Men det lærte anvendte de ikke; de drev landbrug, som fædrene havde gjort det, ekstensivt med får og stude. Kun enkelte havde ko- og svinehold, hvilket vel også til dels skyldtes, at deres jorder var spredte med fenner fordelt hist og her $\mathrm{i}$ kogen.

Der var 9 værtshuse i Højer i 1935, og tallet skal efter sigende have været mere end det dobbelte i 1920. Der var tradition for, når marskbonden havde været rundt at se til får og stude, så skulle han styrkes med noget drikkeligt. På kroen mødtes man, her blev handlet, spurgt nyt og verdens eller $i$ al fald Højers anliggender blev ordnet her. Det kunne let hænde, at det blev en "long Sitzung“, men at komme hjem med en ordentlig "haarbyttel« var bestemt ingen skam, snarere det modsatte. Det skete en aften, at et par stykker var blevet »usattes«. Det kom til klammeri, og sagen kom for retten i Tønder. Som vidne var indkaldt en $æ l d r e$ bonde, der var kendt for det kvantum øl, han kunne konsumere. På dommer Stegmans spørgsmål, om de havde været fulde, svarede han: »De trover $\mathfrak{x}$ it hr. dommer, vi haje da kuns fåt en kasten (kasse øl) vær.«

Selskabeligt havde jeg ingen omgang med mine tyske naboer. Mine indtryk af dem stammer fra samtaler, når vi mødtes i marken, fra samvær på jagter og fra møder i kogsbestyrelsen eller bønderkommunen, og efter et sådant møde har jeg i min dagbog noteret: »Forlad mig min skyld. Jeg kan lide dem.«

\section{Direktør Martin Hammerich}

Det var et konsortium på 9 mand, jeg købte Søgård af. De havde i fællesskab købt den for at bevare den på danske hænder. Af de 9 havde direktør Martin Hammerich 2/10. Blandt de øvrige i konsortiet var direktør P. A. Callø, og han syntes vist, jeg så lidt grøn ud, for han spurgte om min alder, og da jeg oplyste, at jeg var 22 år, erklærede han med et smil, at så var jeg altså gammel nok til selv at skrive under på skødet. Det blev nu mest Martin Hammerich, jeg forhandlede med, og jeg kom i et nært forhold til 
denne prægtige mand, der helt levede op til sin ungdoms idealer.

Han kunne ved første indtryk virke lidt veg og famlende, næsten åndsfraværende; men det var kun hans beskedne væsen, der kom til udtryk på den måde. Han vidste, hvad han ville. For ham var målet lysende klart; han ville tjene Danmark, først og sidst, og aldrig tænkte han på at være $\mathrm{i}$ forgrunden. Han var ganske uden ambitioner for egen person, for ham var det i sjælden grad sagen, det gjaldt. Han søgte ingenlunde de tillidsposter, han beklædte; men han var en mand, man kunne samles om. Ham havde man tillid til, og der blev lyttet til hans ord. Han sad i ledelsen af "Det unge grænseværn «, og man husker ham som myndig mødeleder ved de store årsmøder og en nøgtern rådgiver ved grænserådsmøderne, hvor han uden at virke bagstræberisk kunne sætte tingene på plads. Fra Danske Samfund i 1933 oprettedes, var han formand for denne organisation, og det vil være vanskeligt at overvurdere, hvad Danske Samfund betød i de sidste år inden krigen, og ikke mindst, hvad Danske Samfund betød for det gode danske valg i april 1939, hvor det kunne befrygtes, at hjemmetyskerne kunne vinde endnu et mandat og fremsætte krav om, at grænsen atter skulle rykkes mod nord til Kongeån.

Martin Hammerich sparede sig ikke, han var ustandselig på farten, talte ved møder over hele landet og bragte oplysning til det danske folk; men de fleste kræfter brugte han i Nordslesvig. Er der mon noget forsamlingshus, hvor han ikke har talt?

Martin Hammerich havde et smukt hjem. Kønne gamle møbler. På væggene malerier fra guldalderen, og hele hjemmet var præget af hans fine æstetiske sans. Af og til, når jeg var i Tønder, besøgte jeg ham. Vi havde altid meget at tale om, tidens begivenheder optog os begge meget. Nazisternes succes i Tyskland smittede af på hjemmetyskernes optræden i Nordslesvig, Hammerich var ofte ude for hadske og ganske uberettigede angreb, og det kunne godt, når de blev mest ubeherskede og grove, genere ham lidt, selv om han vidste, at det var propaganda og perfid tale. Det var nu heller ikke alle hjemmetyskere, der havde »Zeitung«s mening om ham. Det var der givet ham beviser for, og det trøstede han sig med, når angrebene var værst.

Det skete også, at jeg var inviteret til middag. Hammerich var ene, og det samme var jeg, og så kunne vi blive et lige antal til 
bridgen efter middagen. Den blev nu sjældent til noget, for også ved disse middage blev de aktuelle forhold $\mathrm{i}$ landsdelen drøftet. Gxsterne ved disse middage var ofte amtmandsfamilierne fra Tønder og Åbenrå, og andre der i kraft af deres stillinger var med til at præge landsdelen. Det var spændende aftener at være med til, for her var det folk med viden og erfaring, der drøftede problemerne, og jeg unge mand sad med vidtåbne oren og sugede til mig.

Også på Kohagen ved den nybyggede fjordvej har jeg været hans gæst. Her havde Hammerich sit fristed, her holdt han ferie med sine søskende på en lille ejendom, han havde købt. Havearbejde holdt han meget af, det var for ham den bedste måde at koble af fra arbejdet. I nærheden lå »Grænsehjemmet«, Det unge Grænseværns lejrskolehjem, hvor Hammerich var primus motor for at få den smukke bygning rejst, og han var særdeles virksom med ideer til bygningens udformning og indretning. Sidste gang jeg besøgte Hammerich var i januar 1940, hvor jeg fortalte ham, at jeg havde forlovet mig med hans niece. Det glædede ham meget: »Så bliver noget af min slægt bosat i Sønderjylland. Hammerich var da sengeliggende og meget træt. Jeg ønskede ham god bedring; men der blev ingen bedring. Jeg havde talt med ham for sidste gang. Da den 9. april kom, lå han på hospitalet, han var så syg, at besættelsen ikke blev ham bevidst; men han havde erfaret, at min kone og jeg var blevet gift den 18. april, og hans hilsen til os modtog vi samtidig med budskabet om hans død. Det hører med til mine gode minder, at jeg har kendt denne uselviske, hjælpsomme mand, der som livsmål ønskede at tjene Danmark i den genvundne landsdel.

Ved hans bisættelse i Løgumkloster var, trods besættelse og vanskelige samfærdselsforhold, den smukke gamle kirke fyldt med kendte og ukendte fra hele landsdelen. Det var betagende at høre Schmidt, Vojensgård, i kirken holde afskeds- og takketale til vennen og medarbejderen $i$ den frlles sag.

Ved mindesamværet $\mathrm{i}$ forsamlingshuset var dette fyldt til sidste plads, og også her blev der talt varmt og godt om den betydning, Hammerichs virke havde haft i Nordslesvig. Det var ikke kun et mindesamvær, det blev tillige et nationalt møde, hvor der i mindet om Hammerich, formanden for Danske Samfund, lå en ubevidst opfordring til sammenhold $i$ de onde år, som vi anede lå foran os, uden vi hin aprildag kunne forestille os, hvordan de blev. 
Hammerich var ikke folkelig; men han trivedes ved folkeligt arbejde, at være igangsætter og skabe en dansk bevidsthed gennem folkeligt arbejde, det var et af hans mål. Skønt han af sind og væsen var meget forskellig fra sønderjyder, forstod han dem, og han følte en stærk samhørighed med den befolkning og landsdel, hvor han valgte at øve sit livs gerning, for som han engang sagde til mig på sin stilfærdige, lune facon, og ledsaget af det kønne smil, han havde: "At bo nord for Kongeåen er som at svømme i fersk vand.«

Hans navn og gerning bør huskes, ja burde skrives, for det genforeningsarbejde, han udførte, står på højde med, hvad andre sønderjyske førere har ydet. Det var med glæde, at jeg indtrådte i en komité, der formidlede et maleri udført og ophængt på genforeningsdagen $1976 \mathrm{i}$ billedsalen på Folkehjem. Ved afsløringen talte Troels Fink. Han havde selv haft et nært samarbejde med Hammerich, og $i$ talen gav han et fint billede af Martin Hammerichs liv og virke.

\section{Familien Kjarby}

Kort efter jeg var kommet til Højer, var jeg på besøg hos fabrikant Kjærby, og det besøg skulle blive begyndelsen til et nært venskab med familien.

A. R. Kjærby havde i 1919 købt et dårligt gående uldspinderi i Højer med den klausul, at kom Højer ikke til Danmark ved afstemningen, skulle handelen gå tilbage. Højer kom til Danmark, og Kjærby blev og skabte sin fabrik. Med en helt utrolig energi, flid og nøjsomhed havde Kjærby sammen med sin kone og bistået af de fire ældste børn oparbejdet den blomstrende virksomhed, som jeg i 1935 lærte at kende som Højer tæppefabrik, der for fuld kraft producerede de kendte Højer tæpper. I foråret 1936 påtænkte Kjærby en udvidelse af fabrikken. Denne udvidelse ville kræve højspænding. Højer havde den gang et lille el-værk, som ikke kunne levere den fornødne kraft. Endvidere skulle der garanteres virksomheden mere vand, og endelig skulle der købes et jordareal til den nye fabriksbygning. El og vand kunne der godt opnåes enighed om; men da man kom til jordkøbet, opstod der vanskeligheder. Fra tysk side ville man ikke sælge. Man kunne godt 
acceptere Kjærby og en mindre virksomhed $\mathrm{i}$ byen, der gav arbejde til byens borgere; men den måtte helst ikke blive for stor, så der blev trukket flere danske stemmer til byen.

»Fatter«, som hele byen kaldte A. R. Kjærby, havde et stærkt temperament, og var vel nok mere handlingens end forhandlingens mand, truede med at flytte sin virksomhed, hvis han ikke fik sin vilje. Det blev kendt, og forskellige byer kom med fordelagtige tilbud, hvis han ville flytte, og en overgang så det virkelig ud til, at Højer tæppefabrik skulle havne i Bogense. Situationen var alvorlig. Det ville være et voldsomt tab for danskheden i Højer, men tillige et vældigt økonomisk tab for byen, idet fabriken og dens ansatte betalte ca. $2 / 3$ af skatterne i Højer.

Byrådet var i en kattepine. De fornuftige hjemmetyskere var ikke glade for udviklingen, og fra dansk side så vi med bekymring på fremtiden. Vort mandattal i byrådet kunne, hvis fabriken flyttede, meget vel blive reduceret til 3. Alle gode kræfter blev nu mobiliseret, og der førtes et utal af forhandlinger. Sorg blev til glæde vendt. Kjærby fik mulighed for at købe det nødvendige jordareal. En ny fabriksbygning skød op, og den danske befolkning drog et lettelsens suk, hvad også mange tyske gjorde.

Med sin dynamik var Kjærby selvskreven som danskhedens leder i Højer, og ikke blot var han rig på ideer, men efterhånden som fabrikken gik godt, og han fik midler, var han meget rundhåndet, når der kaldtes på støtte til danskhedens fremme. Han var formand for Højerhus, og havde en meget væsentlig andel $i$, at det blev rejst. Han var formand for Folkeligt Samfund i Højer, og ligeledes var han formand for Danske Samfund i Højer. Da den danske præst kom til Højer, og der ikke var nogen bolig til ham, købte Kjærby resolut et hus, som pastor Nielsen kunne bebo, til den danske præstegård blev bygget på en grund, som Kjærby havde købt og skænket til formålet.

Fra 1929, til han i 1937 flyttede fra byen, sad Kjærby i byrådet og var her højt estimeret for det arbejde, han ydede for byens trivsel. I 1937 overlod A. R. Kjærby den daglige ledelse til søn og svigersøn, og sammen med sin hustru flyttede han til Kolding; men de kunne ikke undvære Sønderjylland, og året efter slog de sig ned i Åbenrå. Da krigen kom, og det blev vanskeligt at færdes, flyttede de til Tønder, hvor A. R. Kjærby pludselig døde i oktober 1943. Han 
blev begravet i Højer, den by han havde sat et stærkt præg på ved sin faglige og nationale indsats.

Fabrikant Kjærby havde købt Højers nedlagte sygehus, og i den ene halvdel indrettet en stor og venlig lejlighed. Hjemmet var uhyre gæstfrit, og fru Kjærby sørgede godt for gæsterne. Fru Kjærby var født i Hannover, og hun lagde mile mellem sig og preussere, som hun intet godt vidste at sige om, de havde jo annekteret Hannover, hvad hun ikke tilgav dem. Efter sit ægteskab følte hun sig helt som dansk og stod trofast og interesseret ved mandens side $i$ hans virke.

Det forekom mig, at der altid var gæster i hjemmet. Ikke blot blev de forretningsforbindelser, der kom til Højer, bespist; men ofte overnattede de også. Kjærbys hjem var også rammen om bestyrelsesmøder $\mathrm{i}$ de foreninger, hvor han sad som formand. $\mathrm{Og}$ som »sygehuset «, som Kjærbys bolig blev kaldt, var rammen om forretningsmæssige, faglige og nationale møder, så var det også stedet, hvor de gerne så ungdom samlet; der kunne tit være 12-18 mennesker i stuerne. Fru Kjærby var meget musikalsk, og dette havde den yngste datter taget $i$ arv, så der blev spillet og sunget efter Danmarks melodibog, Sigfred Pedersens og Seedorffs viser og Deutsche Volkslieder. I "sygehusets« anden halvdel boede Johannes Kjærby, der var ansat på fabriken og blev dens energiske leder efter faderens død.

Johannes Kjærby mindede i mangt og meget om sin far, han havde samme temperament, så det kunne af og til slå gnister, når opfattelserne var forskellige; men målet for dem begge var fælles, det var fabrikens trivsel. Kjærby var en teknisk begavelse; han opfandt nye vævemetoder og kunne få selv den mest drilagtige maskine til at makke ret. Han var ukuelig i sin kamp mod de vanskeligheder, fabriken senere kom ud for. Hans tidlige død var et stort tab for virksomheden. Han var et menneske med et stort og varmt hjerte, og han sparede sig ingen umage, hvis han på den ene eller den anden måde kunne hjælpe.

Hos Johannes og Mariechen Kjærby stod døren også gæstfrit åben. Hun var datter af den tyske borgmester i Højer, og ægteskabet var således et af de i et grænseland ikke sjældne, hvor to med forskellig national baggrund finder sammen. Det kan give problemer, ikke mindst i en national tilspidset tid, som vi oplevede 
den i de sidste år inden krigen og under besættelsen, men som den gamle fru Kjærby var Mariechen Kjærby usvigelig loyal.

Det var ikke med større begejstring, man i den tyske lejr havde set, at den kønne borgmesterdatter blev gift med sønnen af den ledende dansker, og det fortælles, at den tyske apoteker Nuesse, hvis datter var blevet gift med ingeniør Th. Claudi Westh, og borgmester Hans Andersen ved en mørkningsgrog »begræd « tabet af deres døtre til danskerne, og at Nuesse skulle have givet det udtryk med følgende bemærkning: "Ach ja, lieber Hans, erst nehmen sie unser Land, dann nehmen sie unsere Geld, und nun, nun nehmen sie unsere Töchter."

I det lille hus, der oprindelig rummede butik og beboelse, da Kjærby købte uldspinderiet, var der nu indrettet en hyggelig bolig til svigersønnen Vilhelm Mathiasen. Han var ansat på fabriken, havde den daglige ledelse af kontoret og blev samtidig med Johannes Kjærby udnævnt til direktør. Også i dette hjem kom jeg meget og nød megen gæstfrihed. Med ægteparret Ingeborg og Vilhelm Mathiasen havde jeg samarbejde i blandt andet ungdomsforeningen. Mens Johannes Kjærby ofrede hele sin energi og arbejdskraft på fabrikens trivsel og ikke deltog meget $\mathrm{i}$ det nationale arbejde, så var svogeren mere politisk interesseret, og $\mathrm{i}$ 1945 blev han byens første danske borgmester, en post han varetog, til han ca. 10 år senere flyttede til København.

Jeg havde næppe fået mine papirer flyttet til Højer og meldt mig ind i Højer sogns sygekasse, før jeg skulle opleve den nationale strid, for selv noget så fredeligt som en sygekasse blev $i$ hine bevægede år gjort til et dansk-tysk problem. Hjemmetyskerne var efter nazismens gennembrud i Tyskland blevet meget agressive, ikke mindst i Højer, der var det ene af de to sogne, hvor der endnu 15 år efter genforeningen var tysk flertal i de kommunale råd.

Jeg var altså til generalforsamling i sygekassen. Der var mødt 159 tyske og 148 danske. Bølgerne gik højt. Dirigenten havde svært ved at styre gemytterne. Tyskerne truede med at forlade mødet, men gjorde det ikke. Resultatet blev, at sygekassens bestyrelse, der hidtil havde været sammensat af folk, der var interesserede og sagligt kvalificerede, nu fik tre tyskere ind. Formålet var at sygekassen skulle være en ren tysk ledet institution, og et år senere i 1936 nåede man dette mål, idet det ved denne generalforsamling, 
der var mindst lige så bevæget, fik de sidste tre danske medlemmer stemt ud. Generalforsamlingen i 1936, der er beskrevet i en artikel i Sønderjysk Månedskrift i april 1971, var et eklatant bevis på, at vore hjemmetyske naboer, der levede som ligestillede borgere $\mathrm{i}$ herbergstaten ikke påskønnede det, men kun tænkte på at knægte alt, hvad der var dansk i Højer. Udtrykket »Die gequälte Minderheit «, som hjemmetyskerne omtalte sig i propagandaen, gjaldt i al fald ikke i Højer.

I sommeren 1935 var der med H. P. Hanssen som mellemmand blevet dannet et fadderskab for Højer. Vore "faddere« var større fynske jordbrugere med kammerherre $O$. Vind, Sanderumgård i spidsen som formand, næstformand og kasserer var frk. Sehested, og af andre bestyrelsesmedlemmer, jeg husker, var der stamhusbesidder Hofman-Bang, Hofmansgave og proprietær Greve.

I årene op til krigen kom fadderskabets bestyrelse tit på besøg $\mathrm{i}$ Højer, dels for at sætte sig ind i, hvilke opgaver der skulle løses, og dels for at lære os i Højer at kende. Det var dejligt at træffe disse mennesker, der så levende fulgte med i vore problemer. Gennem min familie var jeg lidt bekendt med kammerherre Vind og hans søn Ivar, der senere skulle afløse sin far som formand. Hofman-Bang kendte jeg også perifert, men jeg kom i nært samarbejde med både Vind og Hofman-Bang. Da jeg $\mathrm{i}$ årene 1937-38 ikke sjældent talte ved D.U.G.-møder på Fyn, havde jeg standkvarter på Hofmansgave og blev meget. forkxlet og hygget om af de fire ugifte søskende, stamhusbesidderen og hans tre søstre.

Det var en morsom oplevelse at være gæst på det smukke Hofmansgave, der ligger lige ud til Store Bælt omgivet af en dejlig park med mange sjældne vækster, der blev hæget om med megen pietet. Det var, som tiden blev skruet 100 år tilbage, for moderne faciliteter som elektrisk lys og w.c. fandtes ikke. Det var et dejligt hjem, fuldt af møbler, ting og billeder, der havde slægtshistorie, og alt var præget af gammel, fin kultur. Det var som at opholde sig i et levende, beboet museum.

Fadderskabet havde, om jeg husker ret, lovet os et bidrag på ca. $5.000 \mathrm{kr}$. i tre år; men med den energi bestyrelsen gik ind for opgaven, blev det til et langt større beløb, og det lykkedes blandt andet for fadderskabet at erhverve en marskfenne, beliggende ved strandvejen lige neden for diget i Højer. Denne fenne på ca. 3 ha 
blev begyndelsen til den danske idræetsplads. Købet lykkedes vist ikke mindst, fordi en anonym ofrede et betydeligt beløb. Denne giver havde, så vidt jeg ved, nogen tilknytning til Højer, var vist vokset op der, og havde på egen krop mærket, hvad det ville sige at være dansk, og nu ville han give danskheden en håndsrækning. Idrætspladsen blev en virkelig håndsrækning, det var en storslået gave af uhyre betydning for dansk ungdom i Højer.

Hidtil havde man spillet fodbold et stykke uden for byen på en tilfældig mark, som venlige bønder fra Emmerlev havde stillet til rådighed; men foruden sportsfolkene skulle der også være plads til stude, så det var en ujævn fodboldbane med kokasser, og disse forhold gjorde det ikke atraktivt at være deltager. $\mathrm{Nu}$ fik vi vor egen plads $\mathrm{i}$ byen, og mange unge, som hidtil ikke havde været med, blev nu aktive. Men der skete yderligere det, at nu fik de danske $\mathrm{i}$ Højer en opgave at løse med at dræne, planere, lave løbebaner, plante læbælte, og det gjorde, at idrætsforeningen fik mange medlemmer, også blandt folk, der ikke var aktive sportsfolk, men som gerne ville give en hånd med. Det var et arbejde, der strakte sig over nogle somre; men man gik til det med begejstring. Jeg var formand for idrætsforeningen i de år, og det var morsomt at være med til at skabe dette lille »stadion«, hvor hver mand fik sit stykke læbælte at holde rent, og hvor vi også fik bygget et lille klubhus. Nogle støbte fundament, andre, der var fikse med sav og hammer, tømrede vægge og tag, og en smed iblandt os sørgede for, at vand blev indlagt til brusebade.

Det var en stolt dag, da alt stod færdigt, og vi kunne holde indvielse af sportspladsen. Dannebrog blev hejst på den store mast. $\mathrm{Vi}$ havde indbudt nabosogne til sportsstævne. Fadderskabet var som giver af pladsen naturligvis også med på festdagen, og Ivar Vind, der var dansk mester $\mathrm{i}$ højdespring, indviede atletikbanen med et flot højdespring.

Pladsen blev stærkt benyttet. Der blev drevet fri idræt, og adskillige tog idrætsmærket. Der blev holdt sportsstævner og fodboldkampe med nabosognene. Der er for mig ingen tvivl om, at sportspladsen var med til at skabe sammenhold blandt ungdommen i Højer, og alle, unge som gamle var stolte af den smukke plads, der var større og kønnere end tyskernes. Nu følte man sig ikke længere som »den fattige Rasmus.« 
Fadderskabet nøjedes ikke med at støtte idrætsforeningen, man gav tilskud til forsamlingshuset i Rudbøl, til arbejdet i Folkeligt Samfund, ungdomsforeningen og var aktivt med $i$ bygningen af den nye danske præstegård. Det var en stor hjælp til danskheden i Højer, der blev ydet af fadderskabet. Det var i en trang tid med til at give os selvtillid og mod til at arbejde videre; vi mærkede, at vi ikke stod alene.

I 1935 fik Højer en dansk præst. Der var gået mange forhandlinger forud, for vi havde en sognepræst, der ganske vist var tysksindet, men som redeligt havde forsøgt at være præst for såvel danske som tyske, og iøvrigt ikke havde taget del i sognets nationale strid. Pastor Braren følte det som et mistillidsvotum til den præstegerning, han havde udført i Højer, at pastor Nielsen nu blev udnævnt til præst for den danske del af menigheden. Til pastor Brarens navn knytter sig et af genforeningsdagenes hjertelige billeder, idet det var præstens plejedatter, kong Christian 10. på sit ridt over grænsen tog op på saddelknappen. Den lille hvidklædte pige på kongens hest, denne spontane handling fra kongens side, var et af de træk hos Christian 10., der var medvirkende til hans uhyre popularitet i Nordslesvig.

Indsættelsen af pastor N. P. Nielsen blev en mærkedag i Højers historie, kirken var stuvende fuld, og ved festen i Højerhus var rammerne også ved at sprænges. Dagen blev foruden at være en kirkelig ligefuldt en national begivenhed, der var med til at trække skellene op.

Pastor Nielsen og jeg kom vel aldrig helt på bølgelængde, dertil så vi for forskelligt på mange områder. Men det er utvivlsomt, at han udfyldte et tomrum i den danske menighed. Han gik stærkt ind i det folkelige, nationale arbejde, og i de år, han virkede i Højer, lykkedes det ham at skabe meget dansk liv i byen. Han stod bag ved oprettelsen af dansk børnehjem og børnehave og senere den danske ungdomsskole.

Landbrugskrisen hvilede endnu tungt. De mange bevægelser skabte uro. L.S. førte sig stærkt frem. Der blev arrangeret bondetog til Amalienborg i juli 1935. Inden året gik til ende blev der udskrevet valg til folketinget. Socialdemokraterne førte valget på devisen: Stauning eller kaos. I Højer spekulerede vi imidlertid ikke så meget i partipolitiske baner, men talte stemmerne i danske 
og tyske. Der var fra valget i 1932 en fremgang på 11 stemmer. Det var beskedent, men dog fremgang. Men malurt var der i glæden, for tyskerne kunne præstere en fremgang på 60 stemmer. En del nationalt indifferente var blevet påvirket af den nazistiske propaganda.

Nazismens hæslige smitte var »føget over hegnet«, og i Højer var der god grobund. Hvor mange, der sluttede sig til, kunne vi ikke vide, men ikke få af vore naboer optrådte med hagekors $i$ knaphullet, og vi kunne også bemærke en del mødeaktivitet. Af og til kunne der sive lidt ud om stridigheder mellem »førerne«. Dønningerne af striden mellem overløjtnant Larsen og Jep Nissen nåede også til Højer, og det skabte en splittelse, der medførte, at flere meldte sig ud af »die Partei«; de vendte dog senere tilbage til folden.

Havde valget ikke vist den store fremgang for danskerne, så tabte vi dog ikke modet. I forsamlingshuset var der i disse år ustandselig noget på programmet. Mindst en gang om ugen var der møde, nogle uger to sammenkomster. Fra denne vinter husker jeg en fascinerende foredragsrække af Claus Eskildsen; men i øvrigt kappedes de forskellige foreninger om at komme med de bedst mulige tilbud. Folkeligt Samfund skaffede gode foredrag. Idrætsforeningen havde gymnastikaftener, der sluttede med opvisninger af karle- og pigehold. Ungdomsforeningen havde dilettantforestilling. Den 10. februar var en af de helt store aftener, da mødte mand af huse for at fejre afstemningsdagen. Selv om bænkene var hårde, kunne vi lide at være med $\mathrm{i}$ »huset« $\mathrm{i}$ fællesskabet.

\section{Rektor A. Egeberg Jensen}

Den 15. juni 1936 fejrede vi, som hvert år på denne dato, genforeningsdagen. Aftenens hovedtaler var lektor, senere rektor A. Egeberg Jensen. Det var første gang jeg traf Egeberg; men det blev et møde, der udviklede sig til et meget nært venskab med denne fine, kloge humanist. Han kom til at betyde meget for mig. I samtaler, gennem brevveksling og på udflugter og ture i Nord- og Sydslesvig, har jeg haft et væld af gode timer i samværet med Egeberg.

Egeberg sluttede sin tale i Højer med et citat fra "Som en 
rejselysten flåde«, idet han sagde: „Danskens lovi krig og fred, være ret og billighed, som kong Volmer ville." $\mathrm{Da}$ jeg ved kaffebordet tilfældigt sad ved siden af ham, hævdede jeg, i min ungdoms ivrighed og optaget af forholdene, hvor tyskerne var ved at jage tæppefabriken ud af byen, og hvor de udnyttede deres flertal hensynsløst, at der kunne være grænser for, hvor megen billighed vi skulle vise, vi måtte også vise tænder fra dansk side. Vi blev ikke færdig med at drøfte dette ved kaffebordet, men aftalte at vi skulle mødes igen. Egeberg var runden af god jydsk bondeæt, var venstremand. Politik som sådan havde dog ikke hans store interesse; men grænselandets politik var han meget optaget af, og i 1920 havde han søgt embede $i$ landsdelen for gennem sit arbejde og sin gerning at være med til at fuldbyrde genforeningen.

Af alt, hvad der skete i 1920, var placeringen af de fire statsskoler i Nordslesvig sikkert noget af det heldigste og mest betydningsfulde for genforeningsarbejdet. Det var endvidere så lykkeligt, at det lykkedes at få fremragende pædagoger anbragt ved alle fire skoler. Jeg erkender, at jeg kun har et nøjere kendskab til lærerkollegiet i Tønder, det var i de år fremragende; men man var vist stort set lige så heldigt stillet $\mathrm{i}$ de tre andre købstæder.

Disse dygtige, unge adjunkter og lektorer gik til deres opgave med idealisme og begejstring, men uden hurrapatriotisme med den hensigt at lære Nordslesvigs unge, hvad dansk kultur og væremåde var, og der blev ikke skelet til, om børnene kom fra danske eller tyske hjem; alle blev behandlet ens, ja, hos en mand som Egeberg, var det sådan, at gjorde han forskel, så var det børnene fra tyske hjem, han ofrede mest tid og kærlighed på, for ham var det en opgave at vende dem mod Danmark, ikke at påtvinge dem en danskhed. Mange af Egebergs »drenge «, der gik ud og ind i hjemmet på Ribe landevej, kom fra hjemmetyske hjem. Egebergs genforeningsarbejde i Tønder, senere som rektor i Haderslev og i krigens vanskelige år i Sønderborg, bar rige frugter.

Egeberg var en poetisk natur, hvilket med al tydelighed fremgår af hans smukke hjemstavnssang, "For en fremmed barsk og fattig -«. Denne sang og »Vi vestjyder trives nu bedst i blæst - var næsten obligatoriske ved hvert møde i Højerhus og iøvrigt i Vestslesvig; men lige så meget jeg holdt af »For en fremmed -«, der så glimrende giver stemningen, blidt og storladent på samme tid, 
lige så brovtende fandt jeg "Vi vestjyder -«, ikke mindst den noget hasarderede påstand, den slutter med.

$\mathrm{Da}$ jeg havde kendt Egeberg et år, fik jeg et vældig rart brev fra ham, og brevet sluttede med et digt, der viser, hvor fint han mestrede poesien:

Hvergang lykken smiler, følger skygger med, somrens dage iler alt for brat af sted. Snart vil stormen bøje træerne mod øst, skylle bølger høje mod vor lave kyst.

Frost vil landet knuge, binde å og fjord, vinternatten ruge malmtung over jord, indtil lærkens sange jublende fra sky, spår de frosne vange: Det blir vår påny.

Danmark, lys og lykke, dine børn du gav. Brede bøges skygge, solskin ved dit hav, kornets sus på sletter frodigt græs i eng, lyse, svale nætter over deres seng.

Når dig storme truer, mulm har skjult din vej, vore hjerters luer lyse skal for dig. 
Blot vi dig må eje,
ved vi, at vi går -
selv ad mørke veje -
mod så lys en vår.

Egeberg lærte mig Angel at kende. I hans Ford kørte vi halvøen igennem på kryds og tværs, fra Flensborg til Kappel over Arnæs og Mysunde til Slesvig. Disse udflugter sluttede vi gerne med en middag i Gnomenkeller i Flensborg. Her gennemgik vi dagens indtryk, eller vi kom i kraftige diskussioner om nationale problemer. Vi kunne aldrig blive færdige med at tale om forholdene nord og syd for Skelbækken. Med sin fine ironi og humoristiske sans fik Egeberg bragt mig ned på jorden, når jeg blev alt for entusiastisk.

Egebergs helbred var ikke stærkt, og i 1938 måtte han på rekreation; han valgte en bjergegn i Sydtyskland, men fandt der var ækelt at være, »-uden for mine vinduer vræler de deres krigssange.« Han var ikke kommet helt til kræfter, da han vendte hjem, og han måtte den vinter sige nej til at holde møder $\mathrm{i}$ forsamlingshusene rundt om $i$ landsdelen, og det var han ked af, "Det frisker mig så meget op at komme ud og tale til og med bønder ", skrev han til mig i et af sine breve. Da Egeberg blev rektor i Haderslev, sås vi desværre ikke så ofte, jeg havde ikke bil, og han var meget optaget af sit nye virke. Tit var han for træt til at besøge mig eller få besøg, men så blev brevene vort forbindelsesled.

Begivenhederne syd for grænsen, tyskernes indmarch i $\emptyset_{\text {strig og }}$ Tjekkoslovakiet og Ruslands angreb på Finland, berørte denne fredens mand stærkt. I et af hans breve hedder det »-gid Fanden vil hente sin gesandt Stalin og tage Adolf med - «, og han gruede for, hvad der ville ske Danmark, når krigen kom. At den ville ramme os, var han overbevist om. Sammen med min kone besøgte jeg ham den 11. april 1940. Jeg var rystet over at se, hvordan begivenhederne havde mærket min ven; det var en syg og træt mand, vi besøgte. Under krigen så vi kun lidt til hinanden, det var i de tider en større rejse at komme tværs over landsdelen.

Vore breve fra den tid viser, hvor forskelligt vi så på forholdene. Egeberg troede fuldt og helt på forhandlingspolitikken: "Jeg er bange for følelsespolitik. Det er godt, at hovedparten af befolknin- 
gen er arbejdere og bønder, de er mindre modtagelige for følelsespsykose. Jeg synes disse rabiate patrioter, hvortil du nok skal høre uden selv at vide det og uden at ville det, er smittet af nazismen, det er dens fanatisme og opgejlede had, der fylder dem, og ikke gammeldansk rolige og besindige følelser.«

Jeg var absolut ikke enig med Egeberg $\mathrm{i}$ sådanne betragtninger, og vi »skændtes « bravt når vi mødtes, uden at det rokkede en tøddel $i$ vort venskab.

Under krigen og i de bevægede år umiddelbart efter levede han efter den rettesnor, han havde nævnt ved vort første møde. "Danskens lov i krig og fred, være ret og billighed.« Og han gav klart udtryk for det, hvor han talte i landsdelen. Han var brobygger. Han betød uendelig meget for mig, og få har jeg beundret så meget som Egeberg.

\section{Gaster}

Jeg havde ofte gæster på Søgård, og det var altid hyggeligt, hvad enten det var familien eller en enkelt ven eller, som det skete, at større grupper kom. Når jeg blader i min gæstebog fra de år og ser ned over navnene, myldrer erindringen om mange gode besø $\mathrm{g}$ frem. Således husker jeg en flok pigespejdere fra Flensborg. Deres energiske leder, Ingrid Jensen, kendte jeg fra Ladelund landbrugsskole, og jeg havde også været på besøg i hjemmet på Frederikshøj. Hun spurgte, om pigespejderne måtte overnatte på Søgård, når de skulle på tur til Vestslesvig. Det blev aftalt, at de skulle være to dage på Søgård, overnatte i høet og have forplejning hos os. Fra Søgård skulle de så gøre ture i omegnen til Emmelev Klev, Trøjborg samt se tæppefabriken. Det blev meget vellykket. Pigerne var rørende glade for alt. Det var for disse bypiger en oplevelse at sove på høloftet, se dyrene i stalden og lege med lam på plænen.

Ingrid fortalte, at pigerne skulle betale $75 \mathrm{Pfg}$. for deltagelsen $\mathrm{i}$ turen; men selv dette beskedne beløb, kunne det for nogle af dem være vanskeligt at skaffe, så de måtte afdrage det over tre måneder.

Jeg havde den ene aften inviteret lærer Marcussen og lokalredaktøren af Flensborg Avis i Tønder, Viggo Lausten. Viggo Lausten, der selv var gammel Flensborg-spejder, talte ved bålet, pigerne 


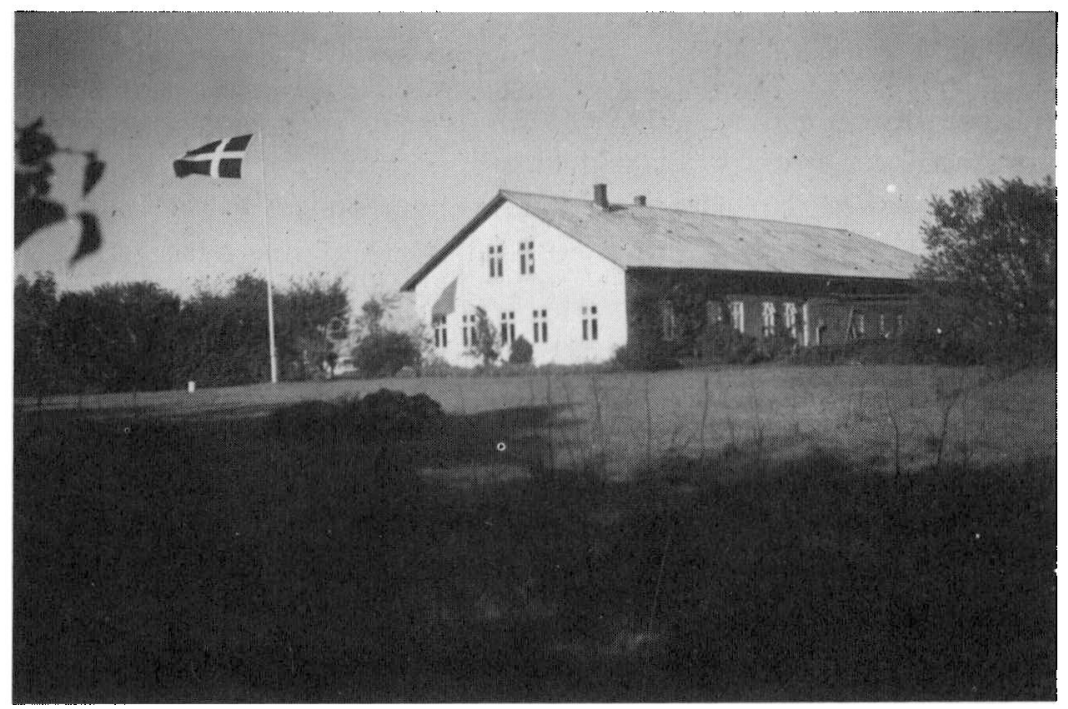

Sommersøndag på Søgård. - Gärden var en vinkelbygning med stuebus mod syd. Herfra gik man ud $i$ stalden og videre til laden, der lä vinkelret berpå. Gärden var bygget 1909 og lå ikke som marskgärde på en varft. (Privat eje)

underholdt med sange, og Marcussen, hvem jeg havde fortalt om spejdernes økonomi, gav løfte om, at D.U.G. ville betale udgifterne ved påsketuren, så det var nogle glade piger, vi dagen efter kunne følge op til diget, hvorfra de cyklede tilbage til Flensborg og hverdagen der. At bekende sig som dansk pigespejder i Flensborg $\mathrm{i}$ 1936 var en stor ting, og disse piger $\mathrm{i}$ alderen 12-15 år imponerede mig ved, at de så tappert vedkendte sig deres danske sindelag.

Flensborg Ungdomsforening kom også cyklende en sommersøndag i 1938 med Dinsen Hansen i spidsen. Vi spiste middag $i$ haven og var på udflugt i Vadehavet. Jeg har et billede af disse unge glade mænd. Størsteparten blev indkaldt året efter, og ikke få af dem skulle i løbet af de kommende år få deres grave på Europas slagmarker.

Sct. Hans aften blev det tradition, at ungdomsforeningen kom til Søgård, hvor vi så havde bål $\mathrm{i}$ haven. Vi havde som regel forskellig underholdning, et år opførte vi »Eventyr på fodrejsen.« Jeg forsøgte også hvert år at skaffe en båltaler. Et år skrev jeg til Mogens Lorenzen. Han kom ikke, men hans afslag var venligt. Det 
lød: »Tak for Deres morsomme brev med den uhyrlige idé. Hvis jeg var ung og rig og havde tid nok, sprang jeg måske på planen; men jeg er gammel og grisk--. Det er noget af det tragisk-komiske ved livets indretning, at mens man er ung og ukendt, er der ingen, der har bud efter en; men når man bliver gammel og berygtet, rives der $\mathrm{i}$ en fra alle sider, og så har man ikke længer selv lyst. God Sct. Hans.“ Også Kaj Munk skrev jeg til. Hans afslag var hans kendte knappe form: "Lader sig ikke gøre. K.M.«

Mellem Tønder statsskole og Sorø Akademi var der hvert år en sammenkomst, skiftevis i Tønder og Sorø. Der var sportskampe mellem de to skoler og desuden udflugter for at lære Vestslesvig og Sjælland at kende. Et år kom de så i en rutebilfuld til Søgård, og jeg var guide for dem til Rudbøl og Højer. De unge soranere var uhyre videbegærlige og meget optaget af det, de så og hørte, der var så uhyre forskelligt fra tilværelsen i Sorø.

Sikre gæster var hvert år sommereleverne fra Ladelund landbrugsskole. Der var som regel mellem 30 og 40 . Heldigvis med velforsynede madkurve, så vi skulle kun sørge for drikkevarer. Jeg havde selv modtaget så meget fra Ladelund, og forstander Overgaard og lærerstaben var mine gode venner, så jeg syntes kun det var rart, at jeg kunne gøre lidt gengæld. Eleverne overnattede i høet, men inden sengetid var vi samlet $i$ haven til jordbær, og her fortalte jeg så om marsken og digernes historie. Jeg sluttede gerne af med at fortælle lidt om den nationale stilling i Højer og forholdene langs grænsen. Morsomt nok førte disse besøg tit med sig, at en, to eller flere af sommereleverne søgte pladser i grænselandet for selv at opleve livet hernede. Men der er også en hverdag i marsken, og den skulle de også høre om, den isolerede beliggenhed, den håbløse jordfordeling, der stod i vejen for rationel drift, og om mangel på vand og veje.

Vejforholdene til Søgård chokerede de unge landmænd. De havde svært ved at forstå, man kunne bo et sted, hvor mælken ikke blev afhentet, og hvor svinebilen kun kom på sommerdage, og det i øvrigt ikke var regnvejr. Jeg kunne fortælle dem, at jeg skulle levere $15 \mathrm{t}$. korn til en banevogn i Højer, og da det var om efteråret, kunne jeg kun have $1 \mathrm{t}$. på arbejdsvognen. Der skulle således køres 15 ture mellem Søgård og Højer eller $120 \mathrm{~km}$. Ja, vejen var virkelig et problem. Som skatteyder, ganske vist beskeden, i Højer søgte jeg 
kommunen om at få vejen udbedret. På borgmesterkontoret meldte man imidlertid hus forbi. Vejen sorterede under bønderkommunen. Oldermanden, som jeg talte med, hævdede, at vejen var god, som den var, og at man vedligeholdt den ved at fylde sand $i$ de værste huller, så bønderkommunen kunne og ville ikke gøre mere. En klage til amtet var også resultatløs. Jeg fik brev fra amtmanden, »- at man fra lodsejerne i Højer mark havde modtaget meddelelse om, at disse har sat vejen i stand for en udgift på ialt $2.200 \mathrm{kr}$. og at markvejen til Søgård nu er i god stand.« Jeg inviterede grev Schack til at besøge mig en vinterdag; men besøget fandt først sted om sommeren, hvor vejen var jævn og tør.

Nå, vi lærte at leve med vejen, så længe vi boede på Søgård; men dens elendighed var medvirkende til, at vi solgte, og indtil Søgård fik fast vej, skiftede den ejer, når børnene blev skolesøgende, for $\mathrm{i}$ vintermørke kunne man ikke sende små mennesker gennem marskfenner og over dybe grøfter.

Når jeg fortalte om hverdagen i Højer, kom jeg også ind på sproget. Der var familier, der havde tysk som hjemmesprog; men en tilfældig turist ville betegne Højer som dansktalende. Det var yderst sjældent, man hørte tysk på gaden, kun det dejlige sønderjyske; men dialekten var vel nok i Højer isprængt en del tyske gloser. For eksempel tog folk altid »æ mantel å.« En vognmand kaldtes » $æ$ foman «, tydeligt stammende fra Fuhrmann. $\mathrm{Og}$ en vognmand kunne godt komme ud for »malør mæ $æ \mathrm{Ge}$ shirr.«

Skulle vi have smedearbejde udført, søgte vi til Døcher smed. Døcher var af frisisk afstamning, vist fra Før og tysk af sindelag. En dag kom en af forsøgsgårdens karle, en sjællænder til smeden, og skulle have en hest skoet. Mens arbejdet står på, taler de om forholdet mellem dansk og tysk, og karlen spørger Døcher, hvorfor han er tysk. Døcher ser lidt på ham og svarer så „Æ har gaven i tysk skol, $\mathfrak{x}$ ha værn tysk soldåt i 9 oer, so $\mathfrak{x}$ ka kun vær tysk. « Til dette svar bemærkede karlen tørt. »Da har Du været heldig Døcher, at Du ikke har været soldat i en negerstamme, for så havde $\mathrm{Du}$ jo været neger.« Døcher havde nær tabt sin hammer, mælet tabte han i al fald, for denne noget holbergske bevisførelse, kunne han ikke give igen på.

Samme Døcher, der ganske givet i sine unge dage havde været en 
stout karl, var nu lidt kroget af alder og arbejde. Han var stolt af den tid, han havde tjent kejseren som Gefreiter i hæren. Nu han var civil, var han stadig befalingsmand; han var nemlig major i brandværnet i Højer, »Feuerwehr« som det hed i daglig tale. Da nazismen slog igennem i Højer, blev det foreslået, at kommandosproget i »Feuerwehr « skulle være tysk, og forslaget blev vedtaget på en generalforsamling med stort flertal.

Selv har jeg ikke været medlem af brandværnet, så følgende beretning har jeg på anden hånd. „Feuerwehr« skulle have øvelse, og var opstillet på skolepladsen vis à vis Kjærbys tæppefabrik. Døcher smed gav nu følgende ordre, på det vedtagne tyske kommandosprog. "Nun stellen wir uns vor, das Kjarbys fabrik den brenner, und dann legen wir die slanger langs $\mathfrak{x}$ skinner, und dann spritzen wir darauf, hier fra $x$ skolplatz. Se det var en ordre både danske og tyske medlemmer i brandværnet kunne forstå.

Man kunne sige om en mand, at han var "galt tysk «, og om en anden, at han var "tumbe dansk «; men jeg er ikke sikker på, at galt kun blev brugt i forbindelse med tysk, og tumbe i forbindelse med dansk. Men en lille dreng, der stammede fra et hjem, hvor xgtefællerne havde hver sin nationalitet, blev efter mange overvejelser, sat i tysk skole. Efter den første skoledag, spurgte moderen ham: "Nå hvordan var der $\mathrm{i}$ skolen? « »Jo det er glant, men de er galt tysk.«

Også »æ Varman«, markmanden, der vandrede fra fenne til fenne med sin "klustagh « på nakken, berettede jeg om. Markmanden er en gammel institution; han omtales $i$ al fald i 1600-tallet, og i mine Højerår blev han stadig på »Persdaw«, den 22. februar fæstet for den kommende sommer. Hans løn var et beløb pr. demat (1 demat ca. 1 td. land) + noget for hver hest, kreatur, får og lam, som han skulle holde øje med. I gamle dage har der vel været en markmand $\mathrm{i}$ alle bondesamfund, men som gårdene blev flyttet ud og jorden arronderet, blev markmanden overflødig, og Højer er et af de få steder, hvor denne ordning har holdt sig til vore dage.

Det var en lang spadseretur, markmanden skulle ud på hver dag. Han begyndte gerne, når det lysnede omkring klokken 4, og var han heldig, kunne han være hjemme ved middagstid. Hvis et dyr lå ned, skulle han hen til det og jage det op, for han skulle konstatere, at dyrene kunne »støtte på alle fire ben.« Men det var langt fra hver 
dag, han nåede hjem til klokken 12. En flok får kunne være brudt ud; så måtte han sørge for, at de blev drevet tilbage i den fenne, hvor de hørte hjemme. En stud kunne være faldet i grøften og sad fast $i$ mudderet. Markmanden måtte så have fat i Falck, eller hvis det var i nærheden af Søgård, så sendte han bud til mig, og så tjente jeg en skilling ved med mine heste at trække studen på det tørre. Det klarede vi ved at lægge et reb om nakken på studen, føre rebet ind $i$ munden, hvor der blev slået en knude. En hammel blev bundet $\mathrm{i}$ rebet, hestene spændt for, og så lod vi dem trække til. Egentlig mærkeligt, at studene kunne holde til den ophaling, for de sad ofte dybt i mudder; men der skete aldrig noget uheld, og når dyrene havde rystet vand og mudder af sig, gav de sig til at græsse ganske upåvirkede af badet. " $\mathbb{E}$ klustagh" var uundværlig for markmanden, for hans vej rundt i fennerne medførte, at han skulle passere brede grøfter og afvandingskanaler.

Denne klustagh eller springstok skal bruges med en bestemt teknik. Er det en grøft med blød bund, og det er de næsten alle, må man ikke stikke stokken ned i midten, for så sker der det pinlige, når man kækt springer ud og er kommet $i$ lodret stilling, at springstokken presses ned i den bløde bund. Springets fart standses, og man skal være meget heldig, hvis man falder ind mod grøftekanten. I de fleste tilfælde vil springeren falde langs med grøften og ende $i$ vand og mudder, og til skaden føjes spot, idet vidnerne altid vil opslå en skadefro latter. Nej, stagen skal sættes på et fast sted i den skråning, man springer fra, så kan man let komme over et vandløb på både 2 og 3 meter.

En særlig slags sommergæster var studenterhøsthjælperne. Jeg var kommet ind i en fin komité; en sådan skal man jo have, med en lang række navne fra land og by, navne der skulle borge for, at studenterhøsthjælpen var en dansk organisation, der intet havde at gøre med hverken arbejdslejre eller nazisme. Studenterhøsthjælpen gik, som det fremgår af navnet ud på, at studenterne skulle tage ud på landet og hjælpe bønderne med at bringe høsten i hus. Gennem 4 år havde vi på Søgård sådanne hjælpere, og det var en stor oplevelse for begge parter, og at det var en god idé at blande by og land sammen $i$ en fælles opgave, er jeg stadig overbevist om. De unge minervadøtre og -sønner opdagede, at der var en verden uden for Frue Plads, og vi bønder konstaterede, at sådan en "studentmager- 
svend « ikke var så tosset, og når vi efter en lang og varm høstdag sad bænket ved aftenkaffen, kom der drabelige diskussioner i gang, og begge parter lærte, at livet kan leves på forskellig vis.

\section{Byrådsvalg 1937}

I 1937 havde vi lidt optimistisk håbet på, at vi kunne mønstre så mange stemmer, at vi kunne få det femte mandat. Optimismen var for stor, der manglede 17 stemmer. Det var lidt bittert, at jeg var et par måneder for ung til at stemme; men godt var det, at min enkelte stemme ikke var udslaggivende. Det ville næsten ikke have været til at bære. Men fremgang var der i det danske stemmetal. Siden sidste byrådsvalg i 1933, var det danske stemmetal steget med 36. Det så vi som et lyspunkt og en opmuntring; men tyskernes stemmetal var også steget. Alle var blevet mobiliseret i begge lejre. Ved valget var stemmeprocenten 94,6, så det var bogstaveligt kun kvinder i barselsseng eller folk, der næsten lå for døden, der ikke mødte op på valgdagen.

Ethvert valg i de år var et nationalt valg, hvor det ikke drejede sig om partipolitik, men var et spørgsmål om dansk eller tysk. I 1933 havde der kun været disse to muligheder, men i 1937 havde socialdemokraterne deres egen liste. Der var dog listeforbund mellem de to danske lister, så ingen stemme ville gå til spilde.

Selve valgdagen var der vældigt liv i byen. Danske flag var oppe. Der var organiseret transport for ældre og dårligt gående, ingen skulle blive hjemme, og vi vidste næsten med sikkerhed, hvilket parti hver enkelt vælger sluttede sig til. Både danske og tyske havde observationsposter, der registrerede, om alle nu mødte frem. En observatør måtte ifølge loven ikke opholde sig i valglokalet; men så indrettede man sig, så man kunne holde døren til Ohlsens hotel, der var valglokale, under opsyn.

Vi danske sad i kaptajn Kiils hyggelige stue, og på den anden side af torvet $\mathrm{i}$ hotel Sylts karnapstue sad tyskerne og gjorde deres notater. Syntes man så, det trak lidt længe ud med, at den og den vælger mødte frem, så sendtes en stafet ud, så at ingen skulle undslå sig for at gå til valg.

$\mathrm{Da}$ valget sluttede, samledes en masse vælgere for at overvære 
optællingen. Tyskerne var naturligvis meget tilfredse med, at stillingen i byrådet var uændret 7 tyske og 4 danske.

Det blev det sidste valg til byrådet inden 1945. Da der normalt 4 år senere skulle være kommunevalg, vedtog folketinget, at der ikke skulle afholdes valg i Nordslesvig. Vi havde hørt, at hjemmetyskerne ikke ville deltage, og rygterne om, at valget ikke ville blive afholdt, begyndte at gå. En dag mødte jeg i Højer en hjemmetysker, der fortalte mig, at kommunale valg i Nordslesvig ville blive udskudt. Han ville ikke opgive sin kilde, men hævdede med stor bestemthed, at sådan var det. $\mathrm{Og}$ ret fik han i sin påstand. Mindretallet ønskede ikke valg. En stor del af dets medlemmer havde meldt sig til tjeneste i SS eller den tyske hær. Andre var beskæftiget uden for hjemstavnen, og blev der valg, ville det tyske stemmetal gå føleligt ned. Besættelsesmagten krævede så, at der ikke blev valg i Nordslesvig, og fra folketinget gjorde man så denne indrømmelse for at bevare "husfreden ". Vi var mange, der fandt det uheldigt, at man med denne lov var med til at markere en grænse ved Kongeåen, en grænse, som man ellers gennem 20 år havde søgt at slette. Jeg kan stadig ikke forstå, hvorfor man ikke lige så vel nord for Kongeåen som syd for den kunne køre livet videre uden kommunevalg.

\section{Kogsbestyrelse og bønderkommune}

Af nysgerrighed og egoisme søgte jeg at komme ind i to bestyrelser i Højer, nemlig i kogsbestyrelsen og i bønderkommunen. I kogsbestyrelsen var det af nysgerrighed og interesse, jeg gerne ville være med. Helt let var det ikke, da man havde, og vist stadig har nogle ganske særlige valgregler; man stemmer efter høveder og ikke efter hoveder. Det skal forstås således, at for det første er folk, der kun ejer 1 ha, slet ikke valgberettigede, for det andet vælger man et bestyrelsesmedlem for hver 100 ha. Jeg var medlem af gruppe 4 . Det var grundejere, der havde mellem 30 og 40 ha. Nu skulle jeg så finde frem til andre grundejere, der ville lægge deres arealer til mine og stemme på mig, så kunne vi få en dansk repræsentation $\mathrm{i}$ bestyrelsen, der ellers kun bestod af tyske bønder.

Af forstander Viggo Nielsen på statens forsøgsgård, der havde nogle arealer i Højer kog og af flere andre danske lodsejere fik jeg fuldmagt til at råde over deres stemmer, og jeg kom så ind $\mathrm{i}$ 
kogsbestyrelsen. Det var en ren hjemmetysk forsamling, der med digegreve Dethlefsen i spidsen, der foruden at være digegreve også var kogsinspektør i Højer kog, bød mig velkommen.

Dethlefsen var tysk, men følte sig i kraft af sin stilling, hvor han sorterede under amtsråd og landbrugsministeriet, som en slags dansk embedsmand og var loyal over for Danmark. Jeg har aldrig hørt ham gå ind for nazismen, på den anden side heller ikke, at han har taget afstand fra den, det skulle da være med en replik om, at han hellere ville være »reich im Heim« end »Heim ins Reich.« Han havde format, var en myndig mand, der var glimrende til at lede et møde, skære igennem og holde sig til sagen. Invitationen med dagsorden for møderne var på tysk, og ved det møde, hvor jeg første gang var med, sagde han: "Ja Poul, her forhandler vi på tysk."

Jeg svarede, at det forbavsede mig, da vi dog befandt os $\mathrm{i}$ kongeriget Danmark. "De e vi wont til, o de hår vi oltins gøe", svarede Dethlefsen. Hertil bemærkede jeg så, at jeg måtte kræve en oversættelse, hvis der var noget, jeg ikke forstod. Det havde digegreven ikke noget imod. Det viste sig nu, at det kun var en påstand, at der blev forhandlet på tysk, for så snart mødet var åbnet, blev der slået over i sønderjysk, så jeg kom aldrig ud for sprogproblemer ved møderne. Jeg gjorde også vrøvl over, at den skriftlige indbydelse til mødet med dagsorden var affattet på tysk. Det lovede Dethlefsen skulle blive xndret, i al fald skulle min indbydelse blive på dansk; men han glemte det hver gang, og hver gang påtalte jeg det. I de år, jeg var medlem af kogsbestyrelsen, nåede jeg ikke at få indbydelsen på dansk.

Disse kogsmøder var af ren saglig art. Der drøftedes, hvor store bidrag, der skulle betales, og hvilke forandringer og forbedringer der skulle ske på diger og kanaler, så møderne forløb altid i en rolig atmosfære. Der kom ikke spørgsmål frem, der berørte forholdet dansk-tysk, når man ser bort fra digegrevens og min lille debat om, hvilket sprog indbydelsen skulle være på. Møderne varede gerne et par timer, og når de var afsluttet, fik vi gerne en grog eller to, inden vi skiltes, og mens den blev drukket, blev der snakket studepriser, landbrug, og i de sidste år krigens gang. De fleste af kogsbestyrelsens medlemmer havde gjort tjeneste i krigen 1914-18, og deres krigsbegejstring var beskeden. 
Efter sådan et møde på Nissens hotel, kom vi ud i skænkestuen,

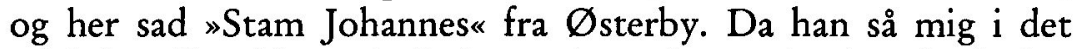
selskab, udbrød han, så alle kunne høre det: „Nå, nå nå, he he her græj græj græjser de de dan dan danske la la lam, mæ mæ mæ de ty ty tyske $\mathrm{u}$ u ulve."

Højer bønderkommune var en gammel institution, dens virke kan spores tilbage til 1600-tallet, og på det tidspunkt var det bønderkommunen, der ledede og styrede i Højer. I Sønderjysk Månedsskrift, januar 1976, har jeg berettet om den. $\mathrm{Nu}$ levede den mest på traditionerne, men havde dog stadig visse praktiske beføjelser. En af dem var vejenes vedligeholdelse, og for at pleje mine interesser heri havde jeg søgt optagelse. Jeg havde læst pastor Rolfs bog om Højer, og her fandtes bønderkommunens vedtægter, af hvilke det fremgik, at man som ejer af mere end 25 demat og bosiddende i Højer, kunne blive medlem af bønderkommunen. Med loven $\mathrm{i}$ hånden henvendte $\mathrm{jeg}$ mig til oldermanden og forlangte optagelse.

14 dage før Pedersdag, den 22. februar blev jeg så inviteret til at møde på Nissens hotel i Højer. Jeg blev budt velkommen af oldermanden, der oplyste, at den officielle optagelse ville finde sted om aftenen, men at jeg allerede nu kunne deltage i mødet. Ligesom kogsbestyrelsen blev mødet åbnet på tysk; men også her slog man straks efter over i sønderjysk. Oldermanden forelagde så det forgangne års regnskab, og man vedtog, hvor mange penge der skulle anvendes til reparation af led og hegn om de fenner, bønderkommunen ejede, ligesom der også hvert år blev bevilliget pengegaver til en rekke gamle og enlige.

Året efter jeg var optaget, foreslog jeg, at vi skulle bruge nogle af indtægterne til istandsættelse af vejen til Søgård, og da jeg ikke var den eneste, der havde interesse $i$, at vejen var farbar, blev der bevilliget $4.000 \mathrm{kr}$. Det hjalp lidt, og jeg havde hermed opnået noget af det, jeg var blevet medlem af bønderkommunen for. Et af krigsårene kom der forslag om, at bønderkommunen skulle yde et tilskud på 200,- kr. til Selbsthilfe, hertil bemærkede jeg, at jeg kun kunne stemme for det, hvis man ville give det samme beløb til D.U.G. Det var synd at sige, at mit forslag faldt i god jord. Det blev ikke vedtaget, derimod fik Selbsthilfe sine penge.

Når regnskabet var forelagt og godkendt, var det næste punkt, at 
der skulle vælges ny oldermand. Dette embede gik på skift hvert år, og ingen kunne undslå sig. Jeg var ikke så læenge medlem af bønderkommunen, at jeg blev oldermand. Det tredje faste punkt var at skrive kontrakt med markmanden om hans lejemål for sommertiden. Det blev nøje ført ind i protokollen, som så blev underskrevet af alle bymændene. Hermed var mødet forbi; men nu skulle der holdes auktion over de jorder, bønderkommunen ejede.

Mens vi havde siddet til møde, var hele skænkestuen på Nissens hotel eller »Stadt Tynner«, som det også blev kaldt, blevet fyldt med byens mandlige befolkning, der tog Pedersdag som en halv fridag og mødte frem for at leje et stykke jord eller blot være med for at høre bynyt. Det var almindeligvis de samme forpagtere, der år efter år lejede de samme arealer; men det kunne ske, at en ikke ville give den forlangte pris, så blev fennen »vacant«, og enhver kunne byde. Auktionen indledtes gerne med, at oldermanden på bønderkommunens regning gav en "Lokalenrunde«, for dermed at skabe større bydelyst og en hyggelig stemning, og gik auktionen godt, hændte det også, at der blev givet endnu en omgang til forsamlingen.

Efter auktionen var der dækket op til middag for bønderkommunens medlemmer. Traktementet var det samme hvert år, nemlig oksesteg og flæskesteg med grøntsager og kartofler, og dertil blev skænket flittigt af brændevin og øl. På Pedersdag havde medlemmerne gratis fortæring af vådt og tørt fra mødets begyndelse og til midnat, hvad man ville nyde efter $\mathrm{kl}$. 24 var for egen regning.

Efter middagen var tidspunktet kommet, hvor jeg skulle optages som medlem. Ind blev båret en stor, smuk punchebolle, og foran gik oldermanden svingende med en stor sølvpuncheske, mens dette optog gik rundt i lokalet blev afsunget en tysk sang: Schier dreissig Jahre bist du alt -. Hvorfor det netop er denne sang, der er en hyldest til en gammel "Mantel«, det er den, der er 30 år, står hen $\mathrm{i}$ det uvisse. Punchebollen blev nu anbragt på bordet foran oldermandens plads. Jeg blev kaldt derhen, og fik forevist den tomme punchebolle, så der skulle jo ikke megen begavelse til at regne ud, hvad der var min pligt som nyt medlem, og servetricen stod da også parat med de fornødne flasker, der skulle hældes $\mathrm{i}$. Oldermanden fyldte nu et glas til os alle, holdt en lille tale, hvor han bød mig velkommen $\mathrm{i}$ laget. Nu var jeg medlem af bønderkommunen. 


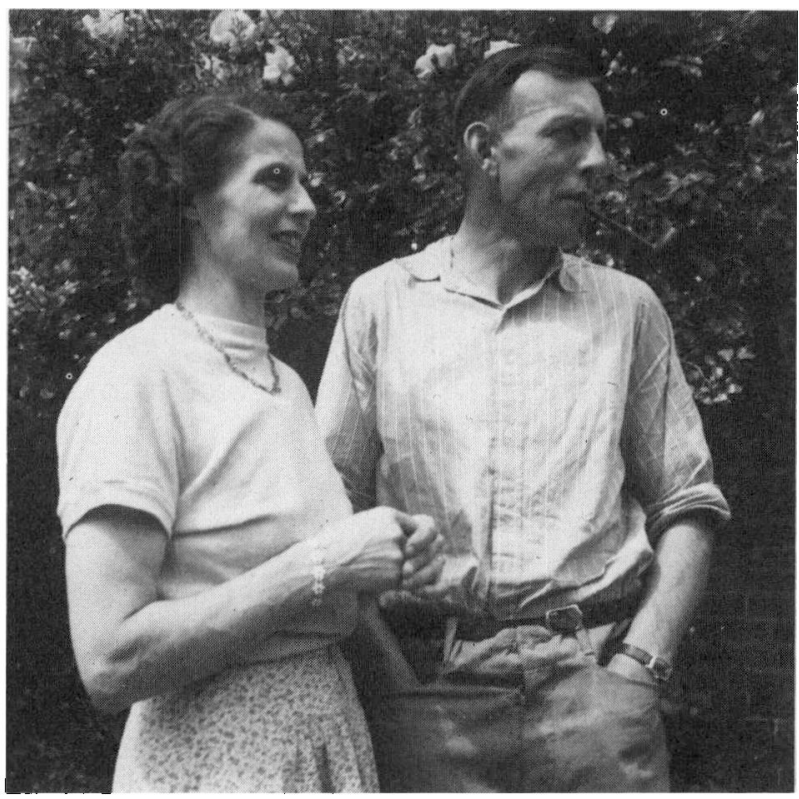

Poul Andersen og hans hustru 1946. (Privat eje)

\section{Det Unge Gransevarn}

Kort efter, at Det Unge Grænseværn var blevet stiftet, blev jeg medlem, og jeg agiterede stærkt blandt mine omgivelser, for at de også skulle melde sig som medlemmer. Jeg havde den glæde, at jeg af og til kunne sende kontoret $\mathrm{i}$ Tønder nye medlemsnavne. I vinteren 1933-34, hvor jeg var på Ladelund landbrugsskole, lykkedes det mig at få over 100 nye medlemmer, og jeg fik derfor arrangeret et møde, hvor Inger Enemark kom til Ladelund og talte. $\mathrm{Da}$ jeg bosatte mig i Højer, havde jeg allerede bekendtskab med Peter Marcussen, Inger Enemark og kaptajn, senere oberst C. G. Bartholdy, og jeg skulle få et nært samarbejde med dem alle tre, og den sidste blev en af mine meget gode venner. Det var derfor naturligt, at jeg meldte mig som tillidsmand for D.U.G. i Højer.

Peter Marcussen havde opgivet sin lærervirksomhed for helt at hellige sig formandshvervet og ledelsen. Det tjener ham til ære, at han skabte denne organisation, som dansk ungdom kunne samles om, og at han gennem sit arbejde pegede på den fare, der lå i 
nazismen. Men nogle af Marcussens ideer var mere uklare, end mange af medlemmerne kunne følge. De ville »kaste af $\mathrm{i}$ det nærmeste $\mathrm{krav} \ll$. For dem var det det nationale og problemerne $\mathrm{i}$ grænselandet, der var det altoverskyggende; det var til at forstå og til at »føle på«. Folkunginstituttet og den meget nordiske tale kom i anden række.

Marcussen forstod, at en organisations medlemmer skal være aktive, medlemmerne skulle mærke, at de gjorde en indsats, og ikke nøjedes med at betale kontingent. Han havde en masse ideer om studiekredsarbejde ude i sognene. Der skulle også oprettes sognearkiver og meget mere. Men de gode ideer blev kun udkastet, aldrig fulgt op. Emblemet skiftede udseende omtrent hvert år. Det var, som kursen virkede lidt svajende; men medlemskaren voksede alligevel.

Af og til ringede Marcussen eller Bartholdy fra kontoret $i$ Tønder, at der var en ungdoms- eller foredragsforening nord for Kongeåen, der gerne ville have en foredragsholder fra Nordslesvig til at fortælle om forholdene i grænselandet, om jeg ikke kunne påtage mig det, og kunne det passe med mit daglige virke på Søgård, sagde jeg ja. Der var $\mathrm{i}$ de år en vældig interesse for grænselandet i hele Danmark, her var noget, de unge kunne engagere sig i, og man ønskede oplysning. Det var derfor en taknemlig og morsom opgave at komme ud på, og jeg har mange muntre minder fra disse foredragsaftener, og jeg lærte en mængde rare mennesker at kende.

Det Unge Grænseværn tog den 20. april 1940 navneforandring til Dansk-Nordisk Ungdomforbund. Dette skridt vakte umådeligt røre. Det var på et fællesrådsmøde blevet vedtaget - dog ikke enstemmigt, men efter hårdt pres fra Peter Marcussen, der ville have sin vilje igennem. Den nordiske linje var sådan set ikke noget nyt, som Marcussen pludselig havde fundet, og den havde ligget ham stærkt på sinde gennem alle årene, hvilket fremgik tydeligt af hans taler og af de talere, der var indbudt til årsmøderne, med oprettelsen af Folkunginstituttet og med bladet Folkung. Navnet Det Unge Grænseværn var godt. Det fængede, nu hed det DanskNordisk Ungdomsforbund. Medlemmerne var stillet over for et fait accompli.

I maj måned var tillidsmændene fra Tønder amt samlet til et mø- 
de på seminariet for at drøfte navneskiftet. Der var et meget stort fremmøde, og der blev rettet mange skarpe angreb på Marcussen. En meget overvældende majorietet talte imod, og som kompromisløsning blev det vedtaget, at navnet Det Unge Grænseværn skulle bevares som undertitel. Jeg var også modstander af navneskiftet. Jeg troede ikke på den betydning, Marcussen lagde i det, og jeg fandt tidspunktet til at skifte, var det dårligst tænkelige; men når sket var sket, mente jeg, at vi måtte få det bedst mulige ud af det, og at det var helt tåbeligt at ødelægge den opbyggede organisation ved negative protestudmeldelser. Tværtimod var tiden inde til samling.

Jeg gik altså - nødtvungent - med til navneforandringen. I øvrigt skete der det, at det gamle navn ikke lod sig udrydde. Blandt medlemmer hed organisationen stadig Det Unge Grænseværn. Trods alle sortseeres spådomme om, at organisationen ville $\mathrm{d} \emptyset$, skete det modsatte; medlemstallet steg, hvilket jeg dog ikke mener skyldtes navneskiftet, men tidens alvor, hvor unge gerne ville være med $i$ en levende organisation, parret med et energisk arbejde af tillidsmænd ud over hele landet.

Jeg gik da også ind for de aktiviteter som D.N.U. satte igang, såsom lejrsport og frivillige arbejdslejre, og ledede blandt andet en lejr i Rudbøl for medlemmer fra D.N.U. I 1943 blev jeg valgt ind i grænserådet. Jeg afløste mejeribestyrer Lorenzen, der havde gjort tiden med siden 1933, men nu ønskede at træde tilbage. På grund af trafikvanskeligheder under krigen og min senere arrestation, blev det nu kun et enkelt møde, jeg deltog i, og i 1945 trak jeg mig atter ud af grænserådet. Endnu nogle år efter krigen formåede D.N.U. at holde sin position, men så svigtede interessen blandt mange unge. Det var ikke længere kamptid. Idag er det sådan, at D.N.U. eksisterer på papiret med en bestyrelse, der forvalter nogle ejendomme og legater, men udadtil har orgnisationen ikke noget ansigt.

Det var en stor oplevelse at være med fra 1933, da Det Unge Grænseværn med sit fanfareagtige navn samlede dansk ungdom. Trist at begejstringens morgenrøde endte i gustent skær, da hverdagen efter krigen satte ind. 


\section{Landevarnet}

I 1927 havde jeg som spejder været med til at sælge andelsbeviser til Landeværnet. For mine sparepenge havde jeg købt en aktie, og med megen interesse fulgte jeg $\mathrm{i}$ Flensborg Avis, hvad der skete $\mathrm{i}$ jordkampen. Kampen om jorden var tæe forbundet med kampen om menneskene. De nordslesvigske bønder var præget af at have besiddet deres gårde i generationer. Der var skabt solid velstand, og med velstand fulgte trangen til oplysning, som under fremmedherredømmet blev søgt på efterskoler, høj- og landbrugsskoler.

Disse dygtige, skolede nordslesvigske bønder skal have en meget stor part af æren for, at landsdelen forblev dansk. De havde, som en selvfølgelig ting, taget kampen op mod fortyskningen, og som en af dem skrev $i$ et brev til en ven under fremmedherredømmet: »Det er den nordslesvigske bondes kultur og karakter, som har fået den historiske opgave at byde den tyske embedsmandsuddannelse trods og sejre over den og dens politiske terror.«

$\mathrm{Nu}$ var det hårde tider $\mathrm{i}$ mange af disse hjem. Krigen 1914-18 havde taget en stor del af den ungdom, der skulle overtage slægtsgårdene, og krigen havde også suget velstanden bort, og for mange var det næsten en håbløs kamp at bevare gård og hjem. Tvangsauktionerne fulgte $\mathrm{i}$ krisens kølvand, og var hyppigere $\mathrm{i}$ Nordslesvig end i det øvrige land.

I denne situation fiskede tyskerne i rørte vande. Vogelgesang havde i 1926 begyndt sin virksomhed. Det har altid været lettere at være idealist, når man har råd dertil, og det skete da også, at der var nogle, der ikke forblev deres idealer tro, men sendte deres børn til en nyoprettet tysk skole, hvilket kunne være prisen for at forblive på det sted, hvortil de var knyttet med slægtens bånd.

Den jordkamp, der i 1920 var blevet afblæst fra dansk side, skulle begynde igen med oprettelsen af kreditanstalt Vogelgesang i 1926. Fra dansk side kunne man ikke bare sidde og se til, så Landeværnet blev oprettet i 1927. Digteren Thøger Larsen ramte stemningen fint med verslinjerne:

At de andre elsker deres - det forstår vi hvis vort vi elsker mindre - da forgår vi.

Advokat Vogelgesang lagde ikke skjul på sine hensigter. I 
forskellige udtalelser til danske dagblade sagde han ret utvetydigt, at man ville opmagasinere jord til tysk ungdom og hverve proselytter blandt nationalt indifferente.

I tilslutning hertil optrådte så demagoger, der $\mathrm{i}$ de mest ubeherskede taler og artikler kastede smuds på herbergstaten. En af dem, der førte sig stærkest frem, var en ung gårdejer fra Als, Wilhelm Deichgräber, der tidligt havde været tilknyttet Cornelius Petersens bevægelse. Han skrev i bladet »Folkets Selvstyre« i 1928 " - vor nationale stilling er i få ord: 'Vi elsker Danmarks folk, flag og konge, men vi hader dets administration'." Denne erklærede kærlighed til Danmark svigtede Deichgräber og gik over i de hjemmetyske rækker. I 1935 var han opstillet som kandidat for Slesvigsk Parti, og han var meget anvendt ved valgmøder. Hans talers facon og demagogi viste med al tydelighed, hvor han havde stået i lære. Ved et valgmøde i Højer, hvor jeg mødte op, blev jeg meget bestemt forment adgang. Det møde var ikke for danske. Før valget udtalte han $\mathrm{i}$ dansk radio, at "på valgdagen vil vi under symbolet, to løver og et hagekors, værge vor hjemegn.« Ved et afstemningsmøde 14. marts 1937 i Slesvig fremturede han, idet han fremsatte den uhyrlige påstand, »-at det engang så rige Nordslesvig er under dansk styre gjort til den fattigste og elendigste landsdel i Europa. For 17 år siden besluttede det danske ministerium at ødelægge Nordslesvig økonomisk for derved at knække det. « Ikke et år efter denne tale, kunne man ved at læse Statstidende se, at det samme samfund, der havde besluttet at knække befolkningen i Nordslesvig, havde ydet Deichgräber et saneringslån på 16.950,-kr.

En anden, der fremførte hadske angreb, var dr. Lorenz Christensen. Han hæudede, at det var jøder og marxister i København, der havde lånt de nordslesvigske bønder penge, for på den måde at få hals- og håndsret over bønderne.

Fra tysk side blev der også $\mathrm{i}$ disse år talt meget om »Bodenverluste«, og man hævdede, at 30.000 ha var »røvet fra det tyske mindretal.« Dette tal kunne ikke tåle en nøjere analyse, og direktør P. A. Callø imødegik da også de tyske påstande, og nævnte i sit indlæg bl.a. de ca. 6.000 ha præstegårdsjord, der vel næppe kunne medregnes, og påviste også andre fejl i den tyske statistik. I al fald var der ingenlunde fra dansk side ført bevidst politik for at 
opkøbe jord, man kan sige tværtimod, ja, som lærer Torp, Tønder udtrykte det: "På det jordpolitiske område, kan man tale om de forspildte chancer.« Havde man fra dansk side villet udnytte situationen, kunne det være sket $i$ betydelig grad, så med denne baggrund virkede den tyske tale hul; men det var nogle pæne tal at anføre, når man mod syd skulle fortælle, hvor hårdt man havde det $\mathrm{i}$ Danmark. Stolligsagen optog i 1937 sindene meget i Nordslesvig. En hjemmetysk gårdejer i Stollig, der ikke kunne klare sine forpligtelser, måtte, som mange andre i de år, og det gjaldt både danske og tyske, se sin gård gå til tvangsauktion. Skønt såvel Vogelgesang som Selbsthilfe var mobiliseret, lykkedes det ikke at skaffe den nødvendige kapital, og gården blev købt af en nordslesvigsk, dansk bonde. Denne handel blev udnyttet stærkt fra tysk side, og vi fik tydelig anskuelighedsundervisning i nazismens sande væsen. Vold og terror blev taget $\mathrm{i}$ anvendelse. Gårdens ruder slået ind, brønden tilsvinet og landbrugsmaskiner ødelagt. Den unge danske bonde skulle fordrives, og den tidligere tyske ejer gøres til martyr. Hele sagen skulle pustes op til at være et bevis for den »brutale undertrykkelse af tyske folkefæller«, der fandt sted $i$ Nordslesvig, og et led i den uro det tyske nazistparti ønskede, der skulle være i Nordslesvig. Det var efter lærebogen, som det skete i Sudeterland.

I 1936 var jeg for første gang til generalforsamling i Landeværnet. Det var en stor oplevelse for mig. Jeg traf her en række af de mænd, jeg kendte af navn. Hans Andersen, Landeværnets myndige formand, Jefsen Christensen, M. Refslund Poulsen, P. A. Callø, Jørgen og Mads Gram, Hans Schmidt og Henrik Petersen for blot at nævne nogle, som jeg gennem mange følgende generalforsamlinger skulle træffe. Det var for mig, der som ung tilflytter var kommet til landsdelen, et af de møder, der gjorde størst indtryk på mig. At høre på mænd, der i deres tidlige ungdomsår i deres hjemsogne, havde været med til at hævde danskheden. Mange af dem havde gjort krigen med gennem alle 4 år, mange af dem havde måttet kæmpe med økonomiske bekymringer efter genforeningen, men lige usvækket var deres kærlighed til Danmark, og lige usvækket var deres ildhu for at bevare landsdelen som dansk. Jeg følte stor ærbødighed for disse mænd.

Landeværnets generalforsamlinger mødte jeg frem til år efter år. 
Det var altid interessante ting, der blev drøftet, og forsamlingen var så tilpas lille og så afgjort sikker, at der af folk som Refslund Thomsen, Jefsen Christensen og Callø med flere kunne gives fortrolige oplysninger. Informationer, der ellers ikke var tilgængelige. Atmosfæren blandt disse mænd, der havde stået sammen siden ungdommen, var af en egen art. De vidste, de kunne stole på hinanden, og de var en gruppe, der havde samme erfaringer. Den nationale modstanders trusler skræmte dem ikke. De udviste ro og besindighed, hvad enten det var $\mathrm{i}$ de sidste bevægede år op til krigen, eller det var under besættelsens usikre og uvisse forhold, og den samme besindighed uden hovering kom til udtryk, da krigen sluttede. Det var en god kreds at færdes i.

\section{9}

Der var udskrevet folketingsvalg til den 3. april, og umiddelbart efter indkaldte Danske Samfund til et møde på Folkehjem. Mødets eneste punkt var organisering af valget. Vi var klare over, at hjemmetyskerne ville gøre alt for at få endnu et mandat $i$ folketinget, og dette måtte ikke ske på grund af sløseri fra dansk side.

Tyskerne begyndte valgkampen med at udsende et blad Hjemstavnens Røst - på dansk. Det blev delt ud til alle hjem, men mere end hjemstavnens røst var det Deichgräbers røst, og den var som sædvanlig perfid og uforsonlig. På tysk side var man beruset af Hitlers succes i München og Sudeterlandets indlemmelse. $\mathrm{Nu}$ skulle man gerne kunne opvise resultat i Nordslesvig, og kunne man få 2 mandater i folketinget, så kunne man tale om en fremgang på $100 \%$. I marts måned var valgkampen oppe på højeste gear. Jeg har $\mathrm{i}$ dagbogen den 19. marts noteret: »Fra tysk side vil man gerne skabe uro, så hjemmetyskerne kan bede om 'beskyttelse'. Det ville passe dem, om de kunne fremvise et 'blodvidne'. Rart at man på dansk side bevarer roen; men jeg begynder at tvivle på, at Danmark er sikret mod at blive overfaldet en skønne dag. Modbydeligt at tænke på, at vi en morgen skulle vågne op og opdage, at Nordslesvig, ja, måske mere er besat af tyske tropper.«

Sidst i marts skulle jeg tale på Ladelund landbrugsskole. Forstander Overgård havde ringet og bedt mig, om jeg ville fortælle 
eleverne om forholdene langs grænsen op til valget. Og der var nok at berette om. Stemningen i Nordslesvig i danske kredse var præget af alvor; men der herskede ingenlunde håbløshed, og der var enighed om, at alle skulle møde frem på valgdagen.

Jeg kunne fortælle om valgkampen, som den blev ført med stor energi fra begge sider. Om de tyske valgplakater - der i øvrigt havde dansk tekst - som tendentiøst fremstillede forholdene i Nordslesvig med ordene: "Vi vil ikke bo i et fattighus « eller »Hvad har Danmark bragt jer andet end skuffelser? Imidlertid er Tyskland blevet stort og stærkt. Det bliver hvert år større og stærkere.« Mere ligeud kunne det næppe siges, at Slesvigsk parti ønskede at komme til Tyskland.

At det var en nazistisk valgkamp, der blev ført, understregedes ved, at en flok unge SS-aspiranter fra en førerskole i Plön deltog aktivt i valgkampen. De drog rundt til danske valgmøder og forsøgte provokationer; de var med til at overmale og klistre plakater på danske forretninger. I Tønder var politiet så heldige at tage tre på fersk gerning og returnere dem til Plön. Fra hjemmetysk side fandt man ikke noget forkert $i$, at udenlandske statsborgere og nazister deltog i valgkampen. Fra Danske Samfunds side var der gjort et stort arbejde, for at der $\mathrm{i}$ hvert sogn blev agiteret for valgdeltagelse, og også Det unge Grænseværns tillidsmænd var aktive i dette arbejde. Valgkampen blev af de store partier ført, omtrent som var de ét parti.

Jeg sluttede min redegørelse på Ladelund med at udtrykke som min overbevisning, at vi nok skulle få alle danske ud at stemme, og at hjemmetyskerne trods alle anstrengelser ikke ville opnå 2 mandater.

Den 26. marts havde tyskerne et stort valgmøde i Tønder. Den tyske avis berettede, at dyrlæge Møller taler med "lidenskabelig kraft «, og han slutter med ordene: "Führer, mach uns frei!«

Den 1. april var der arrangeret en tysk tilkendegivelse i Tønder. Det skulle være et fakkeltog gennem byen. Faklerne blev imidlertid forbudt, men demonstrationsmarchen fandt sted. I anledning af denne demonstrationsmarch i Tønder og en lignende i Åbenrå havde D.U.G. indkaldt sine tillidsmænd til møde på Folkehjem og Tønderhus. Indkaldelsen var strengt fortrolig, og man ville ved mødet få nærmere oplysninger. Hensigten var, at hvis man fra tysk 


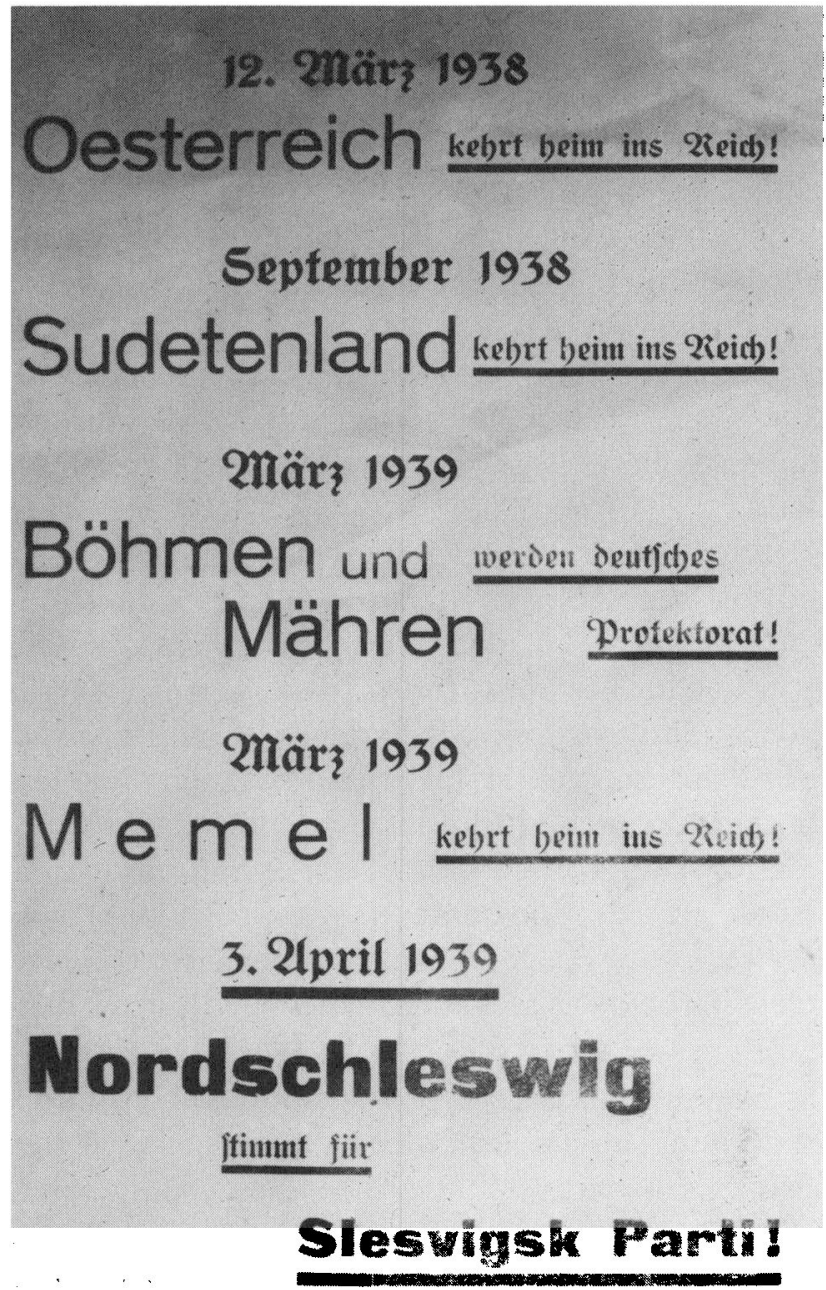

Valgopråb for Slesvigsk Parti 1939. (Historiske Samlinger for Sonderjylland)

side ville øve terror, så var vi en flok unge handlekraftige, der kunne tage kampen op. Heldigvis kunne vi nøjes med at være tilskuere. Det var en ejendommelig oplevelse at overvære denne march gennem Tønders gader. De kom marcherende tre mand i hvert geled med både stor side- og rækkeafstand, så optoget virkede 


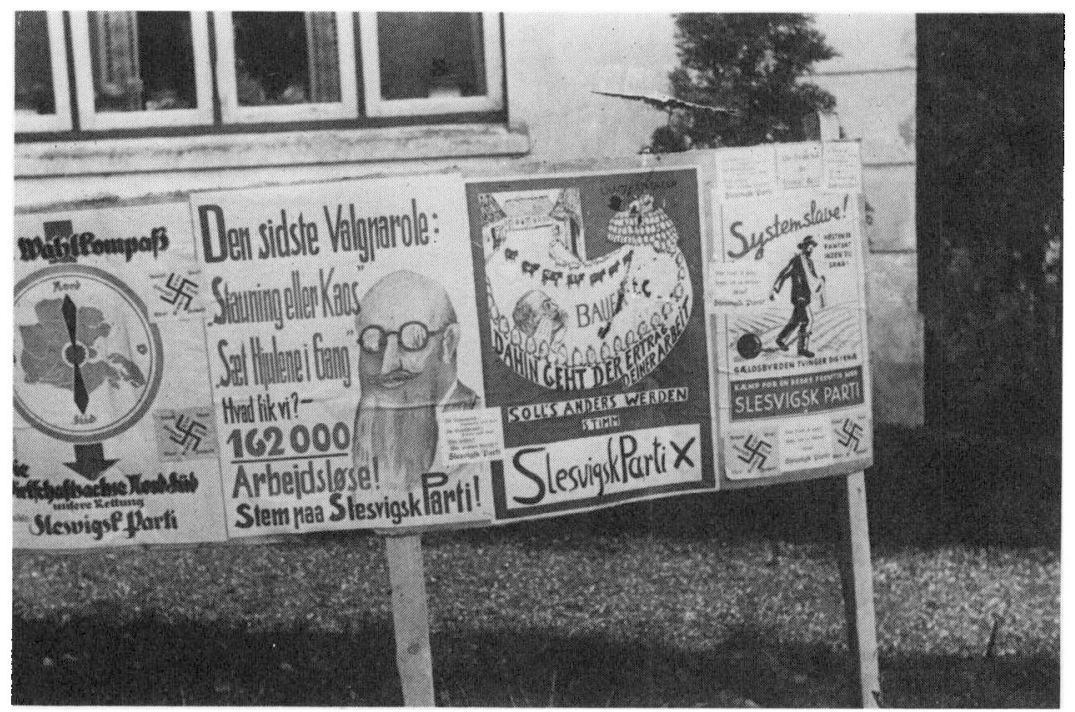

Valgplakater fra Slesvigsk Parti 1939. Bemark plakaten i midten, bvor stats-

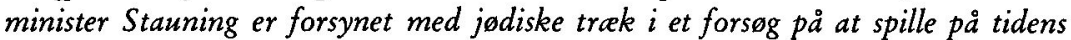
antisemitisme. (Historiske Samlinger for Sonderjylland)

langt. Der var da også ialt med en ret stor gruppe børn, så vidt jeg talte, over 700. Tavse, stirrende lige ud kom de gående. Hverken fra de marcherende eller tilskuernes side hørtes noget. Kun de lange, sorte støvlers taktfaste tramp gav genlyd mellem husene. Gaden lå næsten mørk, da lyset $\mathrm{i}$ de danske forretningers vinduer var eller blev slukket. Samme dag var den mest provokerende valgplakat kastet ind gennem brevsprækken. Den lød:

12. marts 1938.

Østrig vender hjem til riget!

September 1938.

Sudeterland vender hjem til riget!

Marts 1939.

Böhmen og Mähren bliver tysk protektorat!

Marts 1939.

Memel vender hjem til riget!

3. april 1939.

Nordslesvig stemmer på Slesvigsk Parti! 
Så oprandt den 3. april. Aldrig har der vist i Nordslesvig været så mange danske flag oppe. Fra Søgård kunne vi se dem i Højer, Daler, Møgeltønder og Rudbøl. Den alvorlige stemning var slået over til en festlig forventning, og takket været det meget store agitationsarbejde, der var gjort, kom så at sige alle til valglokalerne. Stemmeprocenten lå mellem 92 og 93 . Det blev sent den nat, inden vi kom $\mathrm{i}$ seng. Vi sad ved radioen og fulgte spændt valgresultaterne, som de indløb, og vel hørte vi om fremgang for tyskerne; men den blev overgået af en endnu større fremgang af danske stemmer. Det stod ret hurtigt klart, at faren for, at tyskerne skulle få to mandater, var afværget. Vi fyldtes med stor tilfredsstillelse, og vi glædede os over, at det arbejde, vi så ivrigt havde engageret os $i$, var bragt til en lykkelig afslutning. Resultatet af valget viste, at ca. $85 \%$ af den nordslesvigske befolkning ønskede at høre til Danmark. Det var en dejlig dag, og vi følte det, som havde vi været med til at stemme Nordslesvig hjem.

April var måneden, hvor der var afslutning på vinterens arbejde $\mathrm{i}$ forsamlingshuset, og det var generalforsamlingernes tid. Der var hvert år gymnastikopvisning af pige- og karlehold, og på denne aften var Højerhus fyldt til bristepunktet, og det var en festlig aften. I både ungdomsforening og idrætsforening blev jeg dette år genvalgt som formand, så jeg havde hænderne fulde; men jeg var ung, havde lysten, og jeg havde gode bestyrelser til hjælp. Ikke mindst lærer, senere skoleinspektør, Folmer Christiansen var meget virksom, og han trådte da også til, da jeg i september blev indkaldt til sikringsstyrken. Sommeren 1939 var ualmindelig dejlig, alt groede, som var det betalt for det. Dræningen af mine marker viste sig værdifuld. Det tegnede til en stor og lovende høst. Men ude $\mathrm{i}$ Europa så det ikke godt ud. Trods den ene højtidelige erklæring efter den anden fra Hitler, at nu havde han ikke flere territoriale krav i Europa, begyndte tonen mod Polen at blive mere og mere truende, det var den samme propaganda, som vi kun kendte alt for godt mod $\varnothing$ strig og Tjekkoslovakiet, som vi nu hørte $\mathrm{i}$ radioen, når vi sad ved aftenkaffen, og vi anede, hvor det bar hen. Det var derfor med en mærkelig apatisk følelse, og lidt med en lettelse, at vi den 1 . september hørte om Tysklands overfald på Polen, og hørte om Englands reaktion. Nu ville man ikke længere finde sig i Hitlers skalten og valten. 
Allerede den 1. september blev min ene karl indkaldt. Den 2. september, da vi næsten havde høsten $\mathrm{i}$ hus, rejste vore to studenterhøsthjælpere og dagen efter, da jeg kørte ind $\mathrm{i}$ laden med det sidste læs kløverfrø og høsten dermed var $\mathrm{i}$ hus, kom politibetjent Hartung ind $\mathrm{i}$ gården med min indkaldelsesordre. I løbet af en times tid havde jeg beskikket mit hus. Pasningen af Søgård blev overladt min forkarl, og jeg drog af gårde, for, som der stod i mødebefalingen, hurtigst muligt at begive mig til mobiliseringsstedet, Frederiksberg slot. Næsten resten af året tilbragte jeg $\mathrm{i}$ kongens klæder, først $\mathrm{i}$ midten af december blev jeg hjemsendt og kunne fejre jul på Søgård, hvor jeg også - uden synderlig optimisme - bød 1940 velkommen.

\section{Krigen kommer til Danmark}

Vinteren 1940 var barsk med høje kuldegrader. På vestfronten var der relativt roligt. De to hære stod fast i Maginot- og Siegfriedlinjen. I Finland rasede krigen blodigt. I Danmark vedtog folketinget, at vi skulle forsvare os med alle til rådighed stående midler, og dagen efter hjemsendtes de indkaldte sikringsstyrker, og ca. 500 rekrutter skulle nu forsvare rigets sydgrænse!

Den 10. februar var det 20-årsdagen for afstemningen. Afstemningsfesten, som plejede at være en af de store aftener, kunne på grund af stærkt snevejr og høje kuldegrader kun samle en beskeden skare i Højerhus. Hans Andersen, Kongsbjerg var aftenens taler, og det var en alvorlig tale med frygt for fremtiden.

I radioen slyngede nazispidserne voldsomme trusler ud $\mathrm{i} æ$ teren. Efter en tale af Göring har jeg den 17. februar noteret: »Jeg anser ikke en besættelse af Danmark for at være langt væk. « Hver nat var der motorlarm i luften, når de engelske flyvere var på vej med deres last af løbesedler. Det skete, at de tog fejl af geografien, og vi kunne næste morgen samle $i$ hundredevis af løbesedler op på markerne. Men det skete også, de medbragte bomber og angreb Sild. Vi kunne høre luftværnet glamme, se mundingsglimtene fra kanonerne og se lyskasternes gule fingre, der søgende trak hen over den mørke nattehimmel.

I påsken var der et voldsomt luftangreb på Sild. Fra et loftsværelse kunne vi følge det uhyggelige skuespil. Bombebragene 
var så kraftige, at ruderne klirrede. Brande flammede op, og luften var fyldt af brølende motorer. Det var ligeledes en daglig foreteelse, at tyske jagere strøg ind over gården og videre mod nord ladende hånt om krænkelsen af dansk territorium.

Den 7. april så vi pludselig en dansk militærmaskine komme flyvende langs grænsen, snart steg den op i stor højde for så at dykke ned; hvad var der på færde? Samme aften var der møde i Højerhus, og under mødet kom der bud efter gendarmerne. Under kaffebordet blev det ivrigt drøftet, hvad der var i gærde, men egentlig foruroligede var der ingen, der var.

I forårstiden begynder dagen tidligt på landet; men den 9. april var tyske flyvere endnu tidligere $\mathrm{i}$ luften og overfløj os i større mængder end sædvanligt, ligesom de også fløj længere mod nord uden at dreje af. Den tanke strejfede mig, at de skulle støtte et søslag, men at det var Danmark, der blev angrebet, faldt mig slet ikke ind den morgen. Klokken 6 ringede telefonen; det var min far, der spurgte, hvordan det stod til, og han fortalte, at Danmark var besat. Denne opringning næsten lammede mig. Det forekom mig ufatteligt, at det var sket, at vi ikke var blevet mobiliseret, og at vi kapitulerede næsten uden modstand. Jeg begreb ikke, at denne strålende aprildag kunne være så bitter. Den 9. april erindres jeg stadig om den sorg og ydmygelse, jeg følte i 1940.

I Højer havde nogle af de mest rabiate nazister hejst hagekorset på borgmesterkontoret; men dette ville den tyske borgmester dog ikke tolerere, så det blev ret hurtigt taget ned.

I Tønder var der blevet anbragt et hagekorsflag i kirketårnet, der dog ved politiets indgriben blev fjernet; men mens det endnu hang der, mødtes fru dommer Stegmann og pastor Magle neden for kirken, og fru Stegmann sagde på sin djærve facon: »Gid fanden havde nazisterne.« Til denne lidet kristelige udgydelse havde pastor Magle kun en kort kommentar, nemlig et kraftigt og ment »Amen«

I hjemmetyske kredse glædede man sig, og de invaderende tyske tropper blev hilst med stormende begejstring og som befriere. $\mathrm{Nu}$ ville man slippe for det danske »voldsherredømme«. Den illoyalitet mod Danmark, som siden 1933 havde behersket en stor part af hjemmetyskere, slog ved Danmarks besættelse ud i lys lue, og den skulle i de følgende år derværre give sig større og værre udslag. En illoyalitet mod herbergstaten, som næste generation af hjemme- 
tyskere, hverken skal eller bør lastes for, og for dem, der udviste den, nu er lagt ad acta, men som vi, der oplevede den, ikke kan glemme.

Trods besættelse, mørkelægning, restriktioner og forbud skulle dagens gerning udføres, og livet gå videre. Jeg flagede, som jeg hidtil havde gjort det hver søndag og festdag, og vedblev dermed under hele krigen, også da der fra Dansk Samråd kom forsigtige henstillinger om ikke at gøre det. Med maj måned kom der atter skred i krigsbegivenhederne. Den tyske hærledelse bragte den ene "Sondermeldung " efter den anden, og meddelelsen om, at Paris var faldet, gjorde et dybt indtryk; vi havde ikke tænkt, at Frankrig sådan måtte give op. Det var i nogle dage svært at se lys forude, nu var der kun England på den anden side af vandet, der var Hitlers modspiller, og det var vel nok mere tro end fornuft, der sagde os, at krigen kun kunne ende med, at Hitler og hans regime blev slået.

Genforeningsdagen, den tyvende, blev i Højer ikke fejret som sådan, men som idrætsfest. Vi kunne nu godt have kaldt dagen ved dens rette navn, for vore hjemmetyskere gav udtryk for, at det var lidt af en fornærmelse, at den danske befolkning samledes på denne dag; men de fandt det ganske rimeligt, at enkelte af dem, da Paris faldt, havde luftet deres nye hagekorsflag, stik i strid med gældende lov i den stat, hvis borgere de var.

Hjemmetyskerne var i sommeren 1940 meget optimistiske med henblik på indlemmelse af Nordslesvig i det tredje rige, og som de militære sejre voksede, voksede også deres tro på, at nu skulle den sidste skændsel fra Versailles udviskes, og vi så, der kom flagstænger ved huse og gårde, hvor man i al fald ikke ville hejse danske flag.

Som sædvanlig havde vi inviteret ungdomsforeningen til Sct. Hansfest på Søgård. Jeg fandt, det var vigtigt, at vi danske holdt vore møder, som vi plejede. Det mismod vi eventuelt følte, skulle vi i al fald ikke vise frem. Men Sct. Hansfesten 1940 var måske nok alligevel præget af de mange rygter, der gik, og da vi tog flaget ned, holdt jeg en lille tale, hvor jeg sagde, at måske så meget anderledes ud om få dage, måske ville det være sidste gang for et stykke tid, at vi kunne hejse vort flag, og måske skulle vi også for en periode under tysk herredømme; men det ville kun blive for en kort tid, for det styre, Europa nu oplevede, ville kun leve en begrænset tid. 
Og det blev ved rygterne, vi passerede den 28. juni uden at Nordslesvig kom »Heim ins Reich«. Et par dage senere udstedte dyrlæge Møller forbud mod flagning med hagekors. Tidspunktet for at indlemme "de kartoffelrækker i Nordslesvig" passede ikke med Hitlers planer, og hjemmetyskerne fik pålæg om at stikke piben ind.

Når jeg i disse sommermåneder traf mine tyske naboer i marken eller i Højer, skal det siges, at jeg aldrig hørte provokerende eller hånlige bemærkninger fra dem. De lagde ikke skjul på, at de var begejstrede for den militære fremgang, Hitlers hære havde i Europa, og de mente, at krigen nok ville være endt inden jul, og så ville der findes en ordning for det dansk-tyske grænseproblem. Det var ikke dem alle, der var gennemsyret af den fanatisme, der kom til orde i hysteriske artikler i rubrikken »Unsere Stimme« i den tyske avis. Ganske vist blev der i »Unsere Stimme« ofte talt om det gode forhold mellem dansk og tysk; men det gode forhold kunne kun opretholdes, hvis man fra dansk side helt ville underkaste sig de tyske meninger. De angreb, der i denne rubrik rettedes mod ledende danske og dansk væremåde, var i en sjælden grad med til at forplumre vandene, og artiklerne opnåede kun at gøre skellet mellem dansk og tysk stærkere.

Året 1940 slæbte sig hen. Selv om fremtidsudsigterne ikke kunne kaldes lyse, og rationeringen blev strammet, var tilværelsen på ingen måde uudholdelig, kun lidt besværligere. På Søgård kunne vi især mærke knapheden på petroleum. I november-december fik vi ialt 20 liter til staldlygter og til belysning i stuerne.

Materiel nød kendte vi ikke til, og lærte den heller ikke at kende i krigsårene, og vi følte os skamrost, da nordmændene efter krigen takkede for danskerpakkerne. Det var jo kun af vor overflod, vi havde givet. I den tid, jeg havde boet på Søgård, havde vi ikke leveret mælk, men selv kærnet vort smør. Det fortsatte vi med. Egentlig var det vist ikke helt legalt, men vi var hermed i stand til at hjælpe famlie og venner med smørmærker og selve produktet. Af rug, der blev brændt på en pande på komfuret, malede vi "kaffe«, hvad det absolut ikke smagte af; men det var da en brun drik. Hvedemel fremstillede vi selv på kværnen, og kød og flæsk var på en bondegård ikke noget problem. Krigsårenes julegave til familien var bestandig kvarte grise. 
Tobak var det ret hurtigt småt med, og de mærker, der kom frem, havde deres oprindelse på fynske agre, og solgtes under mærkelige navne som Powhattan, der $\mathrm{i}$ folkemunde blev til puhha, et navn, der ret beset, passede godt til smagen. Cigarhandleren blev en person, der nød megen agtelse, og var han i godt lune, kunne det ske, at han blandt snørebånd og strømper, som han havde fyldt de tomme hylder op med, kunne finde frem til en rygelig cigar nede under disken. Jeg tænkte tit på Hans Beyer, Åsgård, der i 1914, da krigen brød ud, solgte en stud, og for pengene købte tobak og cigarer. I 1932 blev jeg budt af den sidste kasse af dette beredskabslager.

Vinteren 1941 blev også kold og hård. Det første møde, vi havde i forsamlingshuset, var med radioens drengekor dirigeret af Henning Elbirk. De havde aftenen før sunget $\mathrm{i}$ Tønder, og kom nu med rutebil til Daler, herfra gik de under førerskab af adjunkt Finn Christiansen gennem marsken til Søgård, hvor vi havde dækket chokoladebord til dem og havde et par fornøjelige timer med de meget kvikke og søde drenge, før de gik videre til Højer. Højerhus var stopfuldt den aften, og vi nød at høre vore gode, danske sange.

Den 10. februar var der afstemningsfest, der, ligesom året før på den officielle indbydelse, hed familieaften. Pastor Magle var aftenens taler, og han sagde det, man kunne lide at høre, uden at lægge fingrene imellem. Et sådant møde skal ses med tidens øjne, og bedømmelsen må ske efter den tids stemning. Folk kom i forsamlingshuset for at være mellem ligesindede, og møder, hvor tingene blev nævnt ved deres rette navn, havde absolut berettigelse i de år.

Året efter havde vi til afstemningsfesten Jefsen Christensen som taler. Jeg har noteret i dagbogen »Jefsen Christensen talte godt og klogt - næsten for klogt«. Magle og Jefsen Christensen repræsenterede typiske standpunkter under besættelsen, tillige forskellen mellem de gamle nationale ledere og indvandrede rigsdanskere. De danske sønderjyder, der havde levet under fremmedherredømmet og ført kampen på forbilledlig måde, var af den opfattelse, at sådan skulle den også føres under besættelsen. Men krige udkæmpes nu aldrig to gange på samme måde. Der opstod under besættelsen i danske kredse to stærkt divergerende opfattelser af modstandskamp. Det kan dog ikke siges, at den ene helt fulgtes af de fødte 
sønderjyder, og den anden af de indvandrede sønderjyder, nej, skellet gik på tværs og var nok mere et generationsskel; men toneangivende for de to opfattelser blev sønderjyder og rigsdanskere, og det skabte $\mathrm{i}$ besættelsens sidste år kløfter, takket være uovervejede udtalelser fra begge sider.

Alle tanker og samtaler drejede sig om krigen. Danske avisers informationer var præget af tysk censur, og det medførte et utal af rygter. Engelsk radios udsendelser blev næsten troet som evangeliet, ikke mindst fordi man gerne ville tro det og nære egen optimisme, og det kunne der i de første krigsår være al mulig grund til.

Jeg følte tit, at det var for lidt bare at sidde med hænderne i skødet og lade begivenhederne passere. Det var beskæmmende, at Danmark aldrig blev nævnt i forbindelse med undertrykte og besatte lande. Vi havde en særstilling, der ved nærmere betragtelse måtte anses for at være af tvivlsom ære. Vi havde nu været besat et år, og »vi hygged os i smug «. Når jeg var i Tønder og besøgte lektor Rosenkjær og adjunkt Finn Christiansen, drøftede vi bestandig, om vi ikke kunne gøre en mere aktiv indsats. Vi stod famlende, vendte og drejede problemerne, men fandt ingen vej.

En anden af mine venner, kaptajn Bartholdy, sad i terrænsportsrådet. Han spurgte mig, om jeg ikke kunne danne en terrænsportsgruppe i Højer. Formålet var at holde værneviljen levende blandt dansk ungdom, nu hvor ingen blev indkaldt til dansk militærtjeneste. Ifølge en af formålsparagrafferne skulle terrænsport udruste dansk ungdom til at løse de opgaver, der ikke mindst $\mathrm{i}$ vor tid kunne tilfalde ungdommen. Selv om formålet så såre civilt ud, var der ingen tvivl om sigtet, og mange terrænsportsfolk havnede da også i modstandsbevægelsen. Det var ikke svært blandt de unge i Højer at skabe interesse for terrænsport, så til mine andre gøremål i ungdoms- og idrætsforening, blev nu også føjet terrænsport. I forbindelse med dette arbejde traf jeg en ung ingeniør fra Tønder, J. M. Bøge, der var leder af terrænsporten i Tønder. Vi skulle få et nært samarbejde.

Den 22. juni 1941 angreb Hitler Rusland. I sin magtbrynde havde han glemt historiens advarende tale, og vi var overbevist om, at dette skridt ville være med til at forkorte krigen. Ganske vist var der $\mathrm{i}$ begyndelsen store militære sejre for tyskerne; men angrebet 
gik i stå, skønt hærledelsen forkyndte, at nu var alle russiske soldater taget til fange.

Den 22. juni blev en af de dage, hvor man atter som dansk følte skam. Arrestationen af de danske kommunister var, sympati eller ej for dem, en handling, hvor vi trods tysk krav skulle have nægtet besættesesmagten assistance. Sommeren 1941 bød på flere ydmygelser. Torpedobådenes udlevering og oprettelsen af Frikorps Danmark under ledelse af en dansk officer, der talte om at genoprette den danske ære i tysk uniform.

Sidst i juli havde vi 90 gæster til frokost. Laden var tjællet med tæpper, vi havde lånt på Kjærbys tæppefabrik. Borde og bænke var lånt $\mathrm{i}$ forsamlingshuset.De 90 deltog $\mathrm{i}$ en lejr, Dansk Ungdomssamvirke holdt på grænsehjemmet $\mathrm{i}$ Kollund. $\mathrm{Nu}$ var de på tur $\mathrm{i}$ Vestslesvig. De havde overnattet i Tønder, og kl. 9 mødtes jeg med dem ved Højer sluse. Med dem var professor Niels Nielsen, der skulle lede en vandring $i$ vadehavet. Alle smed vi sko og strømper, smøgede benklæderne op og soppede ud i klægen. Niels Nielsen var en strålende og veloplagt leder og fortæller, og i tre timer soppede vi rundt under hans førerskab og fik fortalt om dyre- og planteliv og om dannelse af marsk. $D$ a vi atter nåede til diget, besteg vi cykler og i festligt optog gik det til Søgård, hvor frokosten stod parat. $25 \mathrm{~kg}$. rugbrød og meget andet forsvandt som dug for solen. Mens vi sad ved kaffen fortalte jeg så om digerne, stormfloder og hverdagen $\mathrm{i}$ dette hjørne af Danmark. Det var en meget vellykket dag og morsomt at være med til at arrangere et sådant møde med unge fra det ganske land.

Hen på efteråret mødtes Bøge, Rosenkjær, Finn Christiansen og jeg, og dette møde resulterede $\mathrm{i}$, at Rosenkjær, der gennem sit arbejde med idræt og gymnastik i Tønder amt havde et stort personalkendskab til unge, skulle indkalde til et møde, hvor vi kunne lodde stemningen. Mødet fandt sted i begyndelsen af december. Vi var en lille snes stykker, der var samlet i Rosenkjærs hjem. Unge, der kunne formodes at have samme indstilling som vi, men som måske blot manglede en kontakt. Mødet blev ikke særlig vellykket. Rosenkjær indledte med at sige, at formålet med mødet var at danne en række modstandsgrupper. Direkte imod tanken var nogle af de fremmødte. En anden var så begejstret for idéen, at han ikke kunne tie stille $\mathrm{i}$ sit hjemsogn, men vidt og bredt forkyndte, at 
nu var vi en flok, der ville få fat i våben og bekrige værnemagten. Vi slog så bremserne $\mathrm{i}$, meddelte alle, der havde været til stede, at tanken var skrinlagt, det hele var en misforståelse, kort sagt vi strøede sand på.

Men det blev nu alligevel begyndelsen. Efter vi havde sorteret lidt i deltagerne fra det første møde, var vi en lille flok tilbage. Takket være J. M. Bøges utrættelige energi, kom der resultat, men før vi fandt frem til de rette kontakter, og før vi fik sprængstoffer til sabotagehandlinger, skulle der endnu gå et år.

Bøge var lidt af en landsknægttype. Han var ganske frygtløs, et glad gemyt med en larmende, smittende latter, en fremragende organisator, og så forstod han en ting, at holde mund, og det kneb det meget med i modstandsbevægelsen, i al fald i den første tid. Vi var grænseløst naive dilettanter. Bøge gav kun højst nødvendige oplysninger, og da han i december 1943 måtte flygte til Sverige, havde vi ikke hans kontakter.

At komme fra vest til øst i Nordslesvig blev stedse besværligere. Cyklen var det foretrukne befordringsmiddel; men dækkene begyndte at blive lidt tyndslidte. Rutebiler med generator gik kun sjaldent, og fartplanen blev ikke overholdt, og det samme gjaldt toggangen. Jeg husker et sendemandsmøde i Danske Samfund, hvortil jeg var indkaldt. Mødet var i Åbenrå, og for at nå frem til det måtte jeg aftenen før cykle de $13 \mathrm{~km}$ til Tønder. Her overnattede jeg hos Rosenkjær, så tidligt op for at komme med et tog kl. 6. Efter mødet i Åbenrå nåede jeg tilbage til Tønder 21,30, og så atter en cykeltur på 13 km, før jeg var hjemme på Søgård. Det var, når man ser det nedskrevet, en god portion energi, der skulle til; men i de dage kunne det ikke være anderledes, og så gjorde man det.

Den 30. marts 1942 skulle jeg møde i retten i Tønder. Grunden var, at jeg havde været medindbyder til et møde på Tønderhus, hvor dr. la Cour havde talt i september 1941. Nu var la Cour anklaget for at have talt ophidsende og imod besættelsesmagten. Et par dage for ringede politimester Martensen-Larsen, om jeg ville kigge ind på hans kontor, når jeg kom til Tønder. Det blev en pudsig samtale, for som den korrekte embedsmand han var, ville han ikke forsøge at påvirke mit vidneudsagn; men på den anden side ville han lade mig forstå, at jeg skulle veje mine ord. Hans henvendelse var nu overflødig, for jeg havde allerede taget det 
standpunkt, at jeg et halvt år efter intet kunne erindre af foredraget, og på mig havde talen i al fald ikke virket ophidsende. Jeg kunne kun huske, at foredraget hed »vor neutralitet«, og det, jeg kunne huske, var meget neutralt. Der var et par vidner mere, og deres »hukommelse« var lige så dårlig som min. Det kan ikke have været særligt smigrende for la Cour at høre, at hans talte ord nærmest havde været spildt. Nå, hverken statsadvokaten eller la Cour troede vist rigtigt på os. Dr. la Cour blev da også dømt; men dommen var nok mere inspireret af tyskernes krav om krigsret end af vore vidneudsagn.

D.U.G.s store sommerstævner, der $\mathrm{i}$ årene op til krigen havde samlet $i$ tusindvis af deltagere, var ophørt med besættelsen. Det føltes som et savn, og da Tønder amts idrætsforening under lektor Rosenkjærs ledelse indbød til gymnastikstævne i Tønder, var deltagelsen stor. Hvert sogn i amtet mødte frem med et hold eller to, og desuden var der et hold old boys, hvor jeg var yngste mand; men jeg husker, at der på holdet var deltagere, der havde været aktive i gymnastikarbejdet før 1. verdenskrig, som f.eks. Hans Danielsen, Gerup, Niels Lund, Gammelby og Henrik Petersen, Korntved.

Samtlige ca. 2.000 deltagere marcherede med foreningsfaner og musik gennem Tønder. Der er for mig ingen tvivl om, at dette stæune havde stor betydning. Det store deltagerantal viste, at der blandt de unge var lyst til under krig og besættelse at bekræfte, de var danske. Kort tid efter kom krigen for alvor til Tønder. Jeg var i marken, da to engelske bombemaskiner kom strygende lavt hen over marsken. Jeg husker, hvor dejligt det var at se maskiner med R.A.F.s blå, røde og hvide ringe under vingerne; ellers så vi kun maskiner med sorte kors. Jeg kunne følge maskinerne på deres færd ind mod Tønder, kunne høre bombebragene, se dem vende og atter sætte kursen mod vest. De kom så lavt over jorden, at de forekom mig betænkelig tæt på markled og hegn, og jeg kunne se dem løfte sig over diget.

Den militære hensigt med besøget var vist at bombe Tønder station; men målet blev forfejlet, og det gik ud over nogle nærliggende beboelsesejendomme, og desværre med tab af menneskeliv. Endvidere blev ved skæbnens ironi også det tyske vandrehjem lagt i ruiner, dog uden dræbte eller sårede. Dette blev $\mathrm{i}$ 
den tyske avis slået stort op, som et ualmindelig ondartet og fejgt angreb. Hvad Luftwaffe havde foretaget rundt om på Europas byer, var fuldstændig glemt. I slutningen af 1942, hvor Hitlers hære ikke mere kunne melde om enorme sejre, og hvor tabslisterne også begyndte at berøre mindretallet, var stemningen i hjemmetyske kredse ikke længere så optimistisk, man begyndte at ane, hvor det bar hen. På kogsmøder, hvor man havde talt om, at sejren var lige om hjørnet, blev emnet nu sjældent bragt på bane, og når det blev det, var det med håbet om, at der kunne komme fred snarest muligt med englænderne.

Men i Nordschleswiche Zeitung tordnede pseudonymet »Asmus von der Heide« videre med sine hadske angreb på alt, hvad der var dansk. Hans fanatisme var helt gået over gevind, så han opnåede kun med sine artikler at skabe foragt for sig selv og de meningsfaller, han måtte have.

Hvervningen blandt mindretallet både til SK og til aktiv krigstjeneste blev forstærket. På sessionerne skete det ofte, at gårdejerne blev erklærede "unabkömmlich«, uundværlige; men deres tjenestekarle kunne man godt undvære i produktionen. Dette sociale skel i udvælgelsen til fronttjeneste blev der skumlet lidt over. Det må erkendes, at nogle i mindretallet meldte sig ud fra en indstilling om at høre til det tyske folk, og derfor følte en forpligtelse til at yde en aktiv indsats $\mathrm{i}$ værnemagten. Det er et standpunkt, der kan accepteres.

Året 1943 begyndte som sine forgængere med hård frost og sne. I begyndelsen af januar var jeg til et stort møde i Nyborg. Det var arrangeret af Dansk Ungdomssamvirke. Ellen Malberg sang og spillede, og jeg talte. Jeg fik aftalt med Ellen Malberg, at hun skulle komme til Søgård til Sct. Hansfesten, og med sin sang og recitation gjorde hun denne sommeraften ved bålet til en stor oplevelse.

I marts 1943 blev der udskrevet folketingsvalg. Det var et mærkeligt valg, for det var ikke noget frit valg, og de ting, der normalt kunne tales om i en valgkamp, var det ikke muligt at fremføre. For befolkningen blev valget da også mere en tilkendegivelse af, at man tilsluttede sig et parlamentarisk styre. I den meget store valgdeltagelse på $90 \%$ druknede Fritz Clausens stemmer, og hans parti fik ingen fremgang i mandater. Valget var sådan set et godt valg. I Nordslesvig gik de danske nazister kun knap 300 
stemmer frem. Det tjener absolut den danske befolkning til ære, at kun omkring $1 \%$ bekendte sig til nazismen. Vore hjemmetyskere havde proklameret, at de ikke gik til valg. Til gengald for det mandat, de frivilligt gav afkald på, fik de oprettet et kontor under statsministeriet. Det var en af de mange indrømmelser, man fra dansk side gjorde under besættelsen til de tyske magthavere, og også denne indrømmelse var med til at grave kløften dybere.

En aften $\mathrm{i}$ april kort tid efter valget, var jeg på vej til et møde med terrænsportsgruppen i Højerhus. Jeg så da en hel del hjemmetyskere $\mathrm{i}$ tysk uniform på vej til den tyske sportsplads. Da vi nok kunne have lyst til at se, hvad der var på færde, gik vi derhen og fra en tilstødende have blev vi nu vidner til, at disse SK-medlemmer, der havde meldt sig som »Zeitfreiwillige«, disse danske statsborgere, aflagde ed til Hitler. Der var op mod 100 mand fra Højer og tilstødende sogne, der stod opmarcheret i uniform og med gevær. En »Ortsgruppenleiter«, eller var han »Sturmbannführer«, deres titler var jeg ikke ganske klar på, kommanderede ret og meldte styrken af til en fra Tønder ankommet major i værnemagten, og nu tog han dem i ed. Endnu lyder i mine øren, hvordan han med høj røst beordrede dem at gentage eden. "Ich bin verpflichtet « og 100 stemmer gentog, »Ich bin verpflichtet«. »Dem grossdeutschen Führer Adolf Hitler«, og atter gentog koret. »Adolf Hitler« rungede det tilbage som forstærket ekko over sportspladsen. Det virkede voldsomt på mig. Jeg kendte en meget stor del af dem. Jeg husker, jeg tænkte: »Kun et ord dækker. Landsforræderi«. Det undrer mig stadig, at disse bønder, der overvejende var af dansk rod, og som også overvejende var dansktalende, og som i modsætning til befolkningen i Tyskland kunne være uden frygt for angiveri og kzlejre, ganske ukritisk underkastede sig nazismen. Mindretallet havde dog, som hele det danske folk, haft 7 år fra Hitlers magtovertagelse til besættelsen til at finde ud af, hvad nazismen stod for. De havde haft danske aviser og dansk nyhedsformidling; men de lyttede til falske profeter, og hvad værre var, de troede på dem. Troede så meget, at de blev forført til illoyalitet mod herbergstaten.

Ingeniør Bøge havde faet til opgave at finde frem til egnede nedkastningspladser på vor egn, og i sommeren 1942 kunne der gå besked til London, at den bedst egnede plads lå nord for 


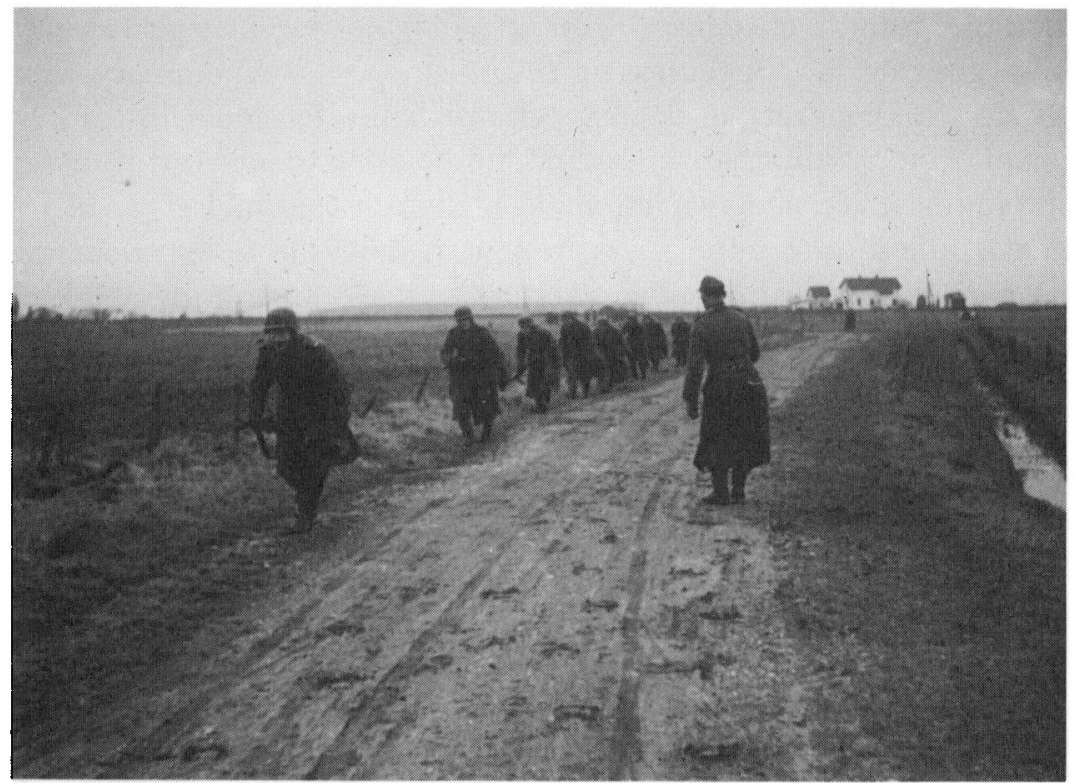

»Zeitfreiwillige« på øvelse. (Historiske Samlinger for Sonderjylland)

Løgumkloster ved Lindet skov. Der kom besked tilbage, at vi kunne vente nedkastning af containere fra engelske fly. Vi var en lille gruppe, der nu forberedte os på at modtage det første sprængstof. Nøje blev det aftalt, hvor vi skulle mødes, og hvilke pladser vi skulle indtage. Cyklerne fik et ekstra eftersyn, for det var $i$ al beskedenhed en tur på $70 \mathrm{~km}$ frem og tilbage. Hver aften lyttede vi til London, spændte på, om der mellem de mange hilsener skulle være hilsen til os.

Aften efter aften lyttede vi, intet skete, og nogen tid efter fik vi at vide, at al nedkastning i grænseegnen var opgivet af sikkerhedsmæssige grunde. Det hjemmetyske element gjorde det for risikabelt, så vi måtte afvente at få våben og sprængstoffer på anden måde. Vi kom hen i 1943, før det lykkedes Bøge gennem kontakter i Århus, at finde frem til en kurér, der skulle bringe de nødvendige ting til Tønder, og en dag stod han så i Rosenkjærs stue med to store kufferter fyldt med sprængstoffet 808 . Nu skulle det bringes til Søgård, hvor depotet skulle være. En dyrlæge, der havde bil, skulle køre det ud til mig. Jeg ringede til ham, at en so havde fået rødsyge, 
hvilket var det aftalte signal til transporten. Imidlertid var det blevet en regnperiode, så bilen ikke kunne køre ud til gården, hvorfor vi aftalte at mødes ved Daler, og her på offentlig vej fandt omladningen så sted fra bilen til min hestevogn. Med i sendingen var en lille instruktionsbog, så vi kunne læse os til, hvorledes bomberne skulle fremstilles og anbringes på skinnerne. Der var også en lille "prøvekollektion« med, så vi havde undervisningsmateriale, og grupperne blev undervist.

Når karl og pige var gået i seng, sad min kone, Bøge og jeg og fabrikerede bomber. 808 har en meget gennemtrængende lugt, og vi fik, når vi havde arbejdet nogle timer med bombefremtilling en kraftig hovedpine. Bomberne var klar til brug, kun tidsblyanterne blev ikke stukket $\mathrm{i}$ detonatoren, og i den kommende tid blev så de første erfaringer gjort med sprængning.

Terrænsportsarbejdet tog også en del af min tid i sommeren 1943. De unge i grupperne spurgte rent ud, om vi ikke snart skulle igang med nogle konkrete sabotageopgaver. De yngste medlemmer vidste ikke, hvor engagerede vi var, og jeg fandt det rigtigst at lade dem $i$ uvidenhed, jeg mente ikke at drenge på 16 år skulle inddrages $i$ illegalt arbejde, selv om det må indrømmes, at mange i denne aldersklasse var stærkt aktive; men det kneb nok lidt for dem at vurdere risiko i forhold til resultat. Bombebragene lød nu over hele landet. Daglig hørte vi om angreb på virksomheder og jernbaner. Modviljen mod besættelsen voksede, og flere og flere blev implicerede i modstandsarbejdet.

Besættelsesmagten blev mere og mere nervøs, og så oprandt den 29. august. $\mathrm{Vi}$ havde travlt med høstarbejdet, men måtte ustandselig til radioen for at høre om begivenhederne, om flådens sænkning, undtagelsestilstanden og regeringens afgang. Det var alvor nu, men alligevel forekom dagen lys, nu var målet blevet fuldt, nu ville vi ikke længere give efter, men var indstillet på at tage, hvad der måtte komme. Noget godt kunne vi ikke vente; men alt var bedre end den bestandige ydmygende underkastelse. Jeg synes mit flag så godt ud den søndag. Vi hørte om arrestationerne af provst Schülein, Claus Eskildsen med flere. Folk der gennem længere tid havde været sjoflet af Asmus von der Heide. Det eneste der kunne bebrejdes dem var, at de åbent havde vedkendt sig som danske.

I Højer var de Zeitfreiwillige også i fuld aktivitet. Patruljerede i 
gaderne i fuld uniform. Alle var de nu ikke helt stolte af at møde deres danske naboer. De havde vist ikke tænkt sig, at det skulle komme så vidt, at de skulle sørge for, at deres danske naboer var inden døre kl. 22. Vi var oprørte over, at vore bysbørn, der var danske statsborgere,nu optrådte som værnemagtens håndlangere.

I september, $\mathrm{i}$ den week-end der stødte op til Christian 10.s fødselsdag, var vi på en lille ferie hos vore gode ven, kaptajn Bartholdys på Munkemølle. Carl Bartholdy ville absolut, at vi skulle blive søndag aften med og først tage hjem om mandagen. $\mathrm{Da}$ han ikke ville høre på mine undskyldninger om travlhed, måtte jeg til sidst sige, at der om mandagen ikke kørte tog, og det gjorde der heller ikke, i al fald ikke det meste af dagen. Vi havde nemlig bestemt at bringe Christian 10. en fødselsdagshilsen ved at lade 50 bomber springe på banestrækningerne Tønder-Bramminge og Tønder-Tinglev. De 49 bomber sprang som planlagt, den sidste var en forsager, og den blev fundet af overbetjent P. Egeberg Andersen, senere kendt som »Sheriffen«. Han havde selv lagt den ud, og afleverede sit fund til tyskerne med alle tegn på forargelse over disse sabotører.

Krigen i Europa gik videre. Den tro, vi fra begyndelsen havde haft på Tysklands nederlag, blev nu realitetsbetonet. Overflyvninger af allierede bombemaskiner hørte til nattens orden. Ofte skete det, at der var kampe med tyske natjagere, og nogle gange havde vi indtryk af, at det foregik over hovedet på os. Vi hørte de larmende motorer og bjæffende maskingeværer. En nat, hvor det var særlig galt, var jeg stået op. Jeg så da brandbomber falde ved Daler og i min egen mark ikke langt fra gården.

Den 11. december om aftenen fik vi besøg af vor gode ven Kjeld Posselt. Kjeld havde været karl hos os, men var nu i sit hjem i Møgeltønder, og aktivt med $i$ en gruppe der. Han var kommet tværs gennem marsken, og var træt af den besværlige tur, og den ellers så rolige Kjeld var bragt lidt ud af fatning. Han fortalte os, at Bøge var kommet cyklende ud til ham og fortalte, at Gestapo havde arresteret Rosenkjær, og at de eftersøgte Bøge, der nu måtte gå i dækning. Kjeld skulle tage ud til os, og vi måtte fjerne lageret af sprængstoffer fra Søgård, og så eventuelt selv gå under jorden.

Det var alvorlige nyheder, og for en gangs skyld var jeg glad for de dårlige vejforhold til Søgård. Gestapo kunne.ikke pludselig komme 
kørende ind $\mathrm{i}$ gården. Vi gik straks i gang. Heldigvis var vort lager på dette tidspunkt ret begrænset. Vi kunne have det i et par sække, og med dem på nakken og en spade $\mathrm{i}$ hånden gik vi ud $\mathrm{i}$ nattens mulm og mørke. Jeg havde netop opgravet en drænsrende, og her begravede vi vort lager. 808 kunne godt tåle fugt, og så måtte vi se, hvordan begivenhederne udviklede sig. Atter hjemme og inden døre drøftede vi, hvad vi nu skulle gøre, om også vi skulle gå under jorden; men resultatet blev, at vi ville søge at få nærmere oplysninger. Kjeld drog atter ud i mørket, og vi gik til sengs og sov de retfærdiges søvn. Næste dag fik jeg en opringning fra politifuldmægtig Bøving, der bad mig komme til Tønder, da der var et lejemål om jagt, han gerne ville tale med mig om. Jeg svarede, at jeg ikke kunne komme til Tønder de første par dage. Nogle timer senere kom Bøving til Søgård. Snakken om jagt var blot et påskud for at få et møde med mig, og han ville, at jeg skulle forsvinde, da der var al mulighed for, at Gestapo også kunne finde frem til mig.

Af Bøving fik vi lidt nærmere enkeltheder om de dramatiske begivenheder i Tønder. Kureren fra Århus var blevet taget. Gestapo havde kørt ham til Tønder, hvor han udpegede huset, hvor han afleverede forsyninger, og da han blev konfronteret med Rosenkjær, var nægtelse ikke mulig. Gestapo lavede nu husundersøgelse, og mens de rodede huset igennem, smuttede Jane Rosenkjær ud af huset og over skinnerne til banegården, hvor hun vidste, Bøge skulle komme med et tog. Hurtigt satte hun ham ind $i$ det skete og fortalte, at Gestapo også havde spurgt efter ham. Resolut stjal Bøge en cykel, spurtede til Møgeltønder, hvor han gav Kjeld Posselt besked. Senere fik vi at vide, at han var cyklet til Bredebro, hvorfra amstlæge Schultz kørte ham til Kolding, og med bistand af forskellige nåede Bøge til København, Sverige og England. Bøving insisterede på, at jeg burde tage bort, men jeg hævdede, at på denne årstid kunne biler ikke køre til gården, og vi kunne på lang afstand se eventuelle "gæster«.

Skete der ikke noget de første dage, regnede jeg med, at Rosenkjær ikke havde haft nødig at fortælle noget om sprængstoffets videre transport. Der skete ikke noget. Uvejret var drevet over for denne gang. Jeg skulle desværre ikke mere træffe Rosenkjær. Hans vej gik over Vestre fængsel, Horserød og til Frøslev. Fra denne lejr blev han, få dage før jeg ankom til Frøslev, deporteret til 
Tyskland. I den berygtede lejr, Schwesing ved Husum, kunne han ikke klare de umenneskelige forhold, nazisterne bød deres fanger. Han døde i december 1944.

Da vi bød 1944 velkommen, var det med ønsket om, at freden ville komme. Men året begyndte lige så ondt, som det gamle var afsluttet. Den 4. januar modtog vi meddelelsen om mordet på Kaj Munk. Selv om vi var hærdede med beretninger om clearingmord, tortur, schalburgtage og lignende, gjorde mordet på Kaj Munk et stærkt indtryk. Men at Gestapo dermed kunne skræmme det danske folk, var en tåbelig tanke. Tyskerne opnåede med deres terrorhandlinger kun det modsatte.

Vi havde i nogen tid talt om at sælge Søgård og flytte til lidt mere »civiliserede« egne, hvor der var fast vej, el og vandforsyning, og hvor det også ville være lettere at få medhjælpere. Jeg averterede Søgård til salg, og den 19. februar dukkede Henrik Petersen, Korntved op. Han kom kl. 13, og kl. 17 havde han købt gården. Minus 2 dage var det nøjagtig 9 år efter, jeg var ankommet dertil, og nu havde jeg skilt mig af med den. Det var ikke helt let at skulle forlade dette sted, hvor jeg havde haft så megen glæde. Det havde fra de første lidt trælse år, hvor jord og bygninger skulle bringes $\mathrm{i}$ orden, til nu, hvor priserne var blevet bedre og det økonomiske udbytte ligeså, været 9 spændende og lykkelige år.

Den 1. maj rullede flyttelæsset ud af gården. Min tid som marskbonde var forbi. 